\title{
Salp grazing: effects on phytoplankton abundance, vertical distribution and taxonomic composition in a coastal habitat
}

\author{
John R. Zeldis ${ }^{1, *}$, Cabell S. Davis ${ }^{2}$, Mark R. James ${ }^{3}$, Sira L. Ballara ${ }^{1}$, \\ Webber E. Booth ${ }^{4}$, F. Hoe Chang ${ }^{1}$ \\ ${ }^{1}$ National Institute of Water and Atmospheric Research (NIWA), Greta Point, PO Box 14-901, Kilbirnie, Wellington, New Zealand \\ ${ }^{2}$ Department of Biology, Woods Hole Oceanographic Institution, Massachusetts 02543, USA \\ ${ }^{3}$ NIWA, PO Box 8602, Riccarton, Christchurch, New Zealand \\ ${ }^{4}$ Biology Department, Universiti Brunei Darussalam, Bandar Seri Begawan, Brunei Darussalam
}

\begin{abstract}
This paper comes from a 3 yr study of environmental effects on egg and larval mortality of snapper Pagrus auratus (Sparidae), during their spring-summer spawning season in the Hauraki Gulf In the first $2 \mathrm{yr}$, the salps Thalia democratica and Salpa fusiformis dominated mesozooplankton biomass in November and December, average chl a concentrations in the mixed layer were reduced and chl a maxima were well below the mixed layer. In the third year, salps were very rare, and the mixed layer was richer in chl $a$ and the chl a maxima were at the bottom of the mixed layer. Diatoms dominated the phytoplankton community in the first 2 yr, especially below the mixed layer, but a more even mix of diatoms, dinoflagellates and flagellates was present in the third year. Averaged mixed layer depth and stratification intensity varied little across the $3 \mathrm{yr}$, suggesting that variation in vertical mixing rates did not drive the phytoplankton contrasts. Salp population grazing rates were high enough to overtake phytoplankton population growth at many sites. However, most sites had lower salp biomass than this, yet the reduction of chl a concentration and deepening of chl a maxima were widespread and temporally persistent. The vertical distributions of chl a were simulated in a nutrient-phytoplankton-zooplankton model which contrasted a salp-dominated community that had high sedimentation of organic wastes with a microzooplankton community within which wastes were recycled in situ. This model, and calculated rates of grazing, sedimentation, and water column mixing, showed that rates of nutrient incorporation into salp mass and sedimentation of waste material from salp grazing would be much greater than mixing of remineralized nutrient back up through the pycnocline. This causes formation of deep chl a maxima which can persist well after significant grazing pressure has dissipated. The variation in phytoplankton taxonomic composition is explained in terms of growth rates of the taxa under different grazing, nutrient and light regimes. The major effects of salp grazing in the coastal environment appear to be to deepen phytoplankton distributions and reduce biomass, rather than to remove phytoplankton biomass from the euphotic zone completely, as can occur in slope and oceanic waters.
\end{abstract}

KEY WORDS: Salps · Phytoplankton biomass · Vertical distribution · Grazing · Zooplankton · Larval fish - Hauraki Gulf

\section{INTRODUCTION}

Grazing by salps and doliolids (Thaliacea) can impact planktonic communities through intense grazing pressure and export of organic material from the upper

•E-mail: zeldisj@frc.maf.govt.nz water column through sedimentation of their faeces and carcasses (Alldredge 1984, Deibel 1985a, Michaels \& Silver 1988, Fortier et al. 1994). This study examines the effects of salp grazing on the structure of the spring-summer phytoplankton community in the Hauraki Gulf of New Zealand. The Hauraki Gulf is a large, shallow bay $\left(4000 \mathrm{~km}^{2}\right.$ area, $60 \mathrm{~m}$ maximum depth) on the northeastern coastline of the North 
Island ( $F \mathrm{lg} .1_{\text {; }}$ Harris 1985) It is warm-temperate, and progressively stratifies from early spring through late summer (Paul 1968, Harrıs 1985). Sampling was done from November (spring) through January (summer) from 1985-86 to 1987-88, as part of a project which described biological oceanographic effects on egg and larval mortality of snapper Pagrus auratus (Spandae), a teleost which supports a valuable fishery in the Hauraki Gulf. Durng the first 2 yr, the salps Thalla democratica and Salpa fusiformas bloomed over large areas of the Hauraki Gulf and dominated mesozooplankton biomass. In the third year, the salps were very rare. Snapper spawn in spring and summer, and survival of furst-feeding snapper larvae was much higher in the third year than the first two (Zeldis 1991, unpubl. data), suggestıng that the trophic environment of the larvae was less favourable when salps had grazed the phytoplankton community.

Salps (and Thaliacea generally) are opportunistic colonizers, and their population sizes can rapidly increase when favourable feeding environments are encountered (Heron 1972b, Deıbel 1985a, Paffenhofer

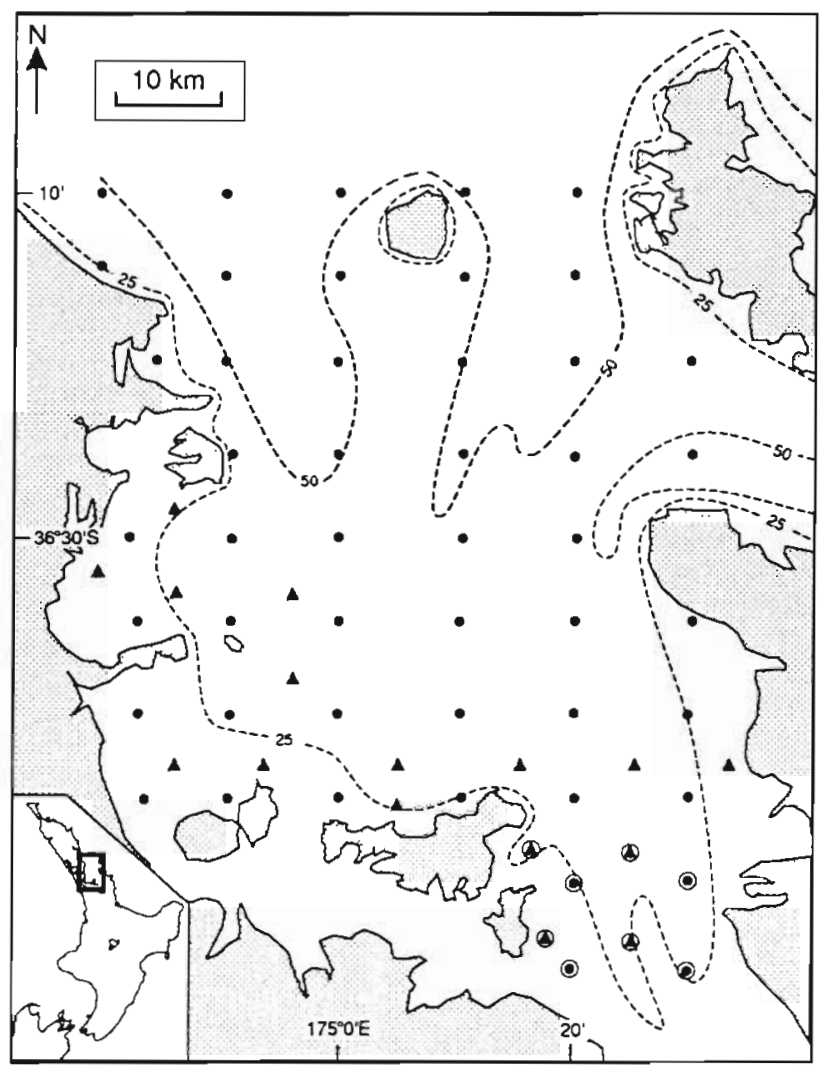

Fig 1 Location of Haurakı Gult in New Zealand (Inset) and map of Haurakı Gulf showing gnd stations and bathymetry. (-) CTD-hose and mesozooplankton stations, (4) mesozooplankton stations only Circled stations in the southeastern Gulf were not occupied in the first year
\& Lee 1987) to the point of dominating zooplankton biomass (Atkinson et al. 1978, Heron \& Benham 1984, Deibel 1985a, Bathmann 1988, Bradford \& Chapman 1988). Rapid population growth is achieved via a number of morphological, behavioural and life history characteristics (Alldredge \& Madin 1982). Their reproduction alternates between sexual and budded generatıons, allowing high fecundity, and high survival of progeny through direct development, viviparity and maternal nutrition. Under favourable conditions young thallaceans can grow very rapidly (Heron 1972a, Heron \& Benham 1985, Le Borgne \& Moll 1986), with generation times considerably shorter than competitors such as planktonic crustaceans (Alldredge \& Madin 1982, Alldredge 1984, Fortier et al. 1994).

Thallaceans are also very efficient grazers. They feed by pumping water through a fine mucous net suspended in the pharyngeal cavity, and can retain and ingest virtually all cell sizes from nanoplankton to netplankton (Alldredge \& Madin 1982, Kremer \& Madin 1992, Fortier et al. 1994). This grazing efficiency, combined with high growth rates, give thaliacean swarms the capacity to reduce local concentrations of phytoplankton and other particulate matter (Hallegraeff 1981, Diebel 1985a, Paffenhöfer \& Lee 1987, Bathmann 1988) and possibly exclude other planktonic grazers through durect competition for food or depression of recruitment of competitors (Fraser 1962, Berner 1967. Alldredge \& Madin 1982, Deibel 1985a).

During grazing by high biomasses of thaliaceans, large amounts of organic material can be exported from the euphotic zone through the production of sinking faeces (Alldredge \& Madin 1982, Alldredge 1984, Morris et al. 1988), as demonstrated in the water column model by Andersen \& Nival (1988) and the trophic web model of Michaels \& Silver (1988). The latter study showed that salps would prevent nutrient recycling within the microbial loop of the euphotic zone by grazing directly on a wide size range of primary producers and microheterotrophs, and exporting this material within sinking faeces.

Thallacean blooms are common in continental slope, shelf and coastal seas. They have been studied in the Middle Atlantıc Bight, USA (Deibel 1985a, Paffenhöfer \& Lee 1987), off western Ireland (Bathmann 1988), in the California Current (Berner 1967), the Mediterranean Sea (Andersen \& Nival 1988, Morris et al. 1988), the East Australian Current (Heron 1972a, b, Hallegraeff 1981. Mullin 1983, Heron \& Benham 1984) and the Hauraki Gulf (Fuller 1953, Jillett 1971). An increasing body of literature is documenting the importance of salp grazing in the dynamics of carbon cycling (Fortier et al. 1994). Except perhaps for the Australıan work, most studies have concerned salps in the open ocean and continental slope, and relatively 
Iittle research has been conducted on the blooms of smaller salps frequently encountered within nearshore, neritic environments. The present study uses field data and modelling to examine the dynamic interactions of salps with phytoplankton biomass, vertical distribution and taxonomic composition in such a coastal environment.

\section{METHODS}

Field sampling. Sampling in the Hauraki Gulf was done over a series of station grids (Fig. 1) during the periods shown in Fig. 2. Stations were occupied during daylight (06:00 to 20:00 h). Conductivity-temperaturedepth (CTD) samples were taken at $1 \mathrm{~m}$ depth intervals, and water samples for chlorophyll a (chl a), nutrients and phytoplankton were taken at a number of discrete depths using vertical profiling from a CTDhose assembly. In 1985-86, water sampling depths were $1,10,25,40$ and $60 \mathrm{~m}$ below the surface. In 1986 87 and 1987-88, water sampling depths were 1, 10, 15 , $20,25,35,45$ and $55 \mathrm{~m}$ below the surface. The CTDhose assembly consisted of a calibrated Guildline CTD probe attached to a weighted $(30 \mathrm{~kg})$ bracket which also held the inlet of a $75 \mathrm{~m}$ long hose attached to a pump on deck. The weight of the probe-inlet assembly was carried by the CTD warp and the hose was paid in and out using a hose winch on deck. In 1985-86 and 1986-87, the hose was $50 \mathrm{~mm}$ i.d. and pumping rate was $125 \mathrm{l} \mathrm{min}^{-1}$, and in 1987-88, the hose was $25 \mathrm{~mm}$ i.d. and pumping rate was $251 \mathrm{~min}^{-1}$. Water was drawn from desired sample depths as monitored by the CTD probe and sampled at the outlet after a period of time sufficient to deliver a sample of water through the hose length. This period was estimated by injecting a slug of methylene blue dye at the inlet and measuring its traverse time. This experiment showed that very little smearing of the slug occurred after it travelled the hose length with either pump system, demonstrating that samples obtained from each depth were uncontaminated by water from other depths.

Mesozooplankton (and salps) were collected using water column-integrated hauls of a plankton net (cylinder-cone design, mouth diameter $=80 \mathrm{~cm}$, mesh pore size $=365 \mu \mathrm{m}$, total open mesh area/mouth area $=$ 12.0). One oblique tow was made at each grid station, from the surface to within $1 \mathrm{~m}$ of the bottom (estimated by wire angle) and back to the surface. Ship speed was 2.0 to 2.8 knots and net warp was paid out and recovered at $1 \mathrm{~m} \mathrm{~s}^{-1}$. Flow through the net was gauged using a calibrated General Oceanics flowmeter suspended inside the net ring. Captured zooplankton were preserved in $4 \%$ borax-buffered formaldehyde. The large quantities of salps caught during the first

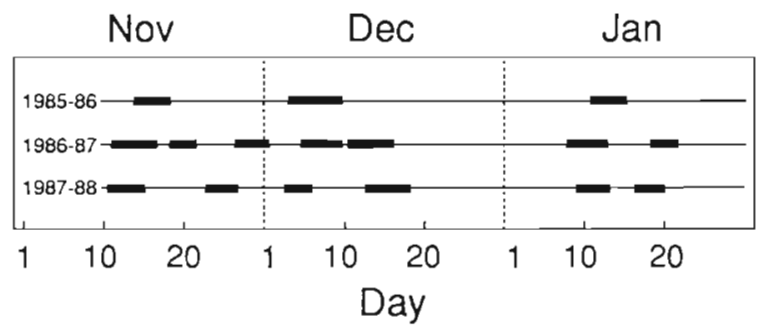

Fig. 2. Dates of grid sampling in this study, 1985 to 1988

2 yr often had to be removed and quantified prior to preservation of the rest of the sample. This was done by thoroughly washing the whole sample through a $3 \mathrm{~mm}$ mesh sieve to remove most of the salps and then recording the drained salp volume. Some depth-stratified tows were also done, using a messenger-activated opening-closing device on the net, and were used to examine salp vertical distribution.

Water sample analyses. In 1985-86, all chl a determinations were made using in vitro fluorometry on filtered water samples. In 1986-87 and 1987-88, chl a was determined using in vivo fluorometry, calibrated using in vitro fluorometry of filtered samples taken from 1 randomly chosen depth from each depth profile. The coefficients of determination $\left(\mathrm{r}^{2}\right)$ of the resulting in vivo versus in vitro correlations ranged from 0.63 to 0.93 (mean $=0.78$, coefficient of variation $=0.05, \mathrm{n}=7$ regressions). For in vivo analyses, water samples were siphoned through a high sensitivity flow-through door on a fluorometer (Turner 111 or Sequoia Turner 112) fitted with a $20 \mathrm{ml}$ sample cell. For all in vitro determinations, 250 to $500 \mathrm{ml}$ of water was filtered through Whatman GF/C filters, and the filters were wrapped in foil and frozen. Samples were analyzed within 2 wk using the acidification method of Strickland \& Parsons (1972). All fluorometers used had lamps, filters and photomultipliers as specified by Lorenzen (1966) and were frequently calibrated against known concentrations of Sigma chorophyll standard. Chl a concentration, corrected for phaeopigments, was calculated according to the method of Strickland \& Parsons (1972). Phytoplankton nitrogen was estimated from chl a concentration by assuming a carbon to chl a ratio (C:chl a) of 100 and a 15:1 carbon to nitrogen ratio (see 'Discussion').

Nitrate concentrations were assayed over profiles done in November, December and January of 1985-86 only. The filtrates from chl a filtrations were frozen on board and analyzed in the laboratory using an automated cadmium column method (Stainton 1974).

Primary production rates were assayed in November 1985 and November 1986, using the ${ }^{14} \mathrm{C}$ uptake technique described by Booth \& Søndergaard (1989). Samples from the surface $1 \mathrm{~m}$ were incubated for 4 to $6 \mathrm{~h}$ 
under light conditions and temperatures representative of the surface layer in a deck incubator. In November 1985, the samples were filtered with Millipore filters $(0.45 \mu \mathrm{m})$ and in November 1986 with Nuclepore filters $(0.20 \mu \mathrm{m})$. The carbon taken up and immediately released from the phytoplankton as extracellular organic carbon during the incubations was also measured in 1986, and this uptake was subtracted from the rates used here.

Phytoplankton species composition. Phytoplankton species composition was studied using whole water samples preserved in Lugol's iodine. The sampling for phytoplankton was not done regularly over the grids. Therefore, in choosing phytoplankton samples for analysis, an attempt was made to select samples from each cruise giving an even spread of samples across the Gulf, and among depths. This was not possible in November 1985 or in January in all 3 years. Also, few samples were taken in the outer Gulf. Therefore, only inner Gulf samples taken in December 1985 and in November and December 1986 and 1987 were used.

In laboratory analysis, each phytoplankton sample was mixed and a subsample (usually $100 \mathrm{ml}$ ) was removed and left to settle for $24 \mathrm{~h}$. The supernatant was pipetted off, and the remaining $10 \mathrm{ml}$ of settled volume was placed in a counting chamber and left to settle for a further $24 \mathrm{~h}$. Using an inverted microscope at $200 \times$ magnification, phytoplankton were identified and counted in 36 evenly arranged fields of view over the bottom of the chamber. If less than 100 cells were seen, a second chamber was counted. Small flagellates ( 4 to $7 \mu \mathrm{m}$ in diameter) were counted in 10 randomly selected fields of view at $400 \times$ magnification. To estimate carbon contributed by each species, the principle dimensions of a representative sample of each species in each sample were measured, and the method using volumes of geometrical solids and volume-carbon regressions described by Chang (1988) was then applied. The picophytoplankton, $<2 \mu \mathrm{m}$, were beyond the resolution of the transmitted light microscope, and were not included in this species composition study. Booth \& Søndergaard (1989) showed that in Hauraki Gulf waters picophytoplankton contributed about $20 \%$ of the total water column chl a during spring and summer 1986-87

Upon analysis, the ratios of carbon to chl a $(\mathrm{C}$ : chl a) were found to be unrealistically low (mean $=9.8, \mathrm{SE}=$ $1.2, n=56$ ). These ratios could realistically be expected to range from about 30 to over 100 (Eppley et al. 1979). This underestimation was probably mostly due to sample degradation, because the samples were not analyzed until 1990, up to $5 \mathrm{yr}$ after collection of the first samples in 1985. Therefore, the samples were not used to estimate $C$ : chl a ratios and were used only to examine species composition. It was assumed that species composition differences seen between years were not caused by differential rates of degradation in samples of different ages. Re-examination of 1987 samples 1 yr after the original analysis showed that differences in species composition that were detected the previous year between these samples and the 1986 samples still existed, supporting this assumption. The failure to count the carbon due to picophytoplankton (Booth \& Sendergaard 1989) also would have contributed to the underestimate of $\mathrm{C}: \mathrm{chl}$ a ratios, but not to the extent of fully correcting the underestimation.

The objective of the analysis was to look for patterns in species composition between samples, so the species biomasses were converted to proportions of the total biomass in each sample. These proportions were arcsine transformed (Underwood 1981). Similarity among stations was measured using the Czekanowski coefficient (Field \& McFarlane 1968), and the resulting matrix of similarity values was sorted by the group average method (Mountford 1962) to form a cluster diagram of percentage similarity. The patterns found by clustering were compared with those found using the ordination technique of nonmetric multidimensional scaling (MDS) implemented using SYSTAT statistical software (Wilkinson 1988).

Mesozooplankton analyses. Mesozooplankton samples were subsampled using a Folsom plankton splitter until at least 100 individuals of the most common organism were present. The organisms in the subsample were identified and counted. Nitrogen biomasses associated with the organisms were estimated. First, wet weight was estimated from length, using relationships for the taxonomic groups given by Davis \& Wiebe (1985). Literature values of adult lengths were used for the copepods and cladocerans (Dakin \& Colefax 1940). For Nyctiphanes australis, the average of lengths of calyptopis, furcilia I and II stages were used (Sheard 1953), because only these stages were caught. Maximum lengths for chaetognaths, larvaceans, small medusae and caridean, anomuran and brachyuran larvae were obtained from measurements of individuals in samples. Nitrogen was estimated from wet weight by using wet weight-carbon relationships for the taxonomic groups (Davis \& Wiebe 1985) and assuming a carbon to nitrogen ratio of 4.1 for crustacea and chaetognatha (Omori 1969) and 4.2 for larvaceans and medusae (based on the salp ratio; Madin et al. 1981). Nitrogen was estimated for the salps by assuming that drained salp volume was equivalent in weight to an equivalent volume of seawater (i.e. that $1 \mathrm{l}$ of drained salps weighed $1 \mathrm{~kg}$ ) and using a wet weight to $C$ ratio of 272.5 (Curl 1961) and a C:N ratio of 4.2 (Madin et al. 1981).

Nutrient-phytoplankton-zooplankton model. To study the potential effects of salp introductions and 
subsequent bloom formation in the Hauraki Gulf on phytoplankton biomass and vertical distribution, a vertical model of nutrient-phytoplankton-zooplankton (N-P-Z) dynamics was developed with spatially dependent diffusion and self-shading by phytoplankton. The essential features of the model include: (1) saturating grazing by microzooplankton on phytoplankton and rapid remineralization of microzooplankton faeces and losses due to death; (2) linear grazing by salps on both microzooplankton and phytoplankton up to clogging concentrations of food; and (3) remineralization of salp faeces and carcasses at the bottom of the water column, simulating rapid sinking of these particulates and leading to depletion of total nitrogen $(N)$ in the upper layers. The dynamics are given by:

$$
\begin{aligned}
\frac{\partial P}{\partial t}= & \mu P \frac{I}{K_{i}+I} \frac{N}{K_{n}+N}-g_{s} S P(1-f) \\
& -g_{m} M \frac{P}{K_{p}+P}+\frac{\partial k}{\partial z} \frac{\partial P}{\partial z}
\end{aligned}
$$

$$
\frac{\partial S}{\partial t}=\gamma \alpha g_{s} S(P+M)(1-f)-d_{s} S-e S f+\frac{\partial k}{\partial z} \frac{\partial S}{\partial z}
$$

$$
\begin{aligned}
\frac{\partial M}{\partial t}= & \gamma \alpha g_{m} M \frac{P}{K_{p}+P}-g_{s} S M(1-f) \\
& -d_{m} M+\frac{\partial k}{\partial z} \frac{\partial M}{\partial z}
\end{aligned}
$$

$$
\begin{aligned}
\frac{\partial N}{\partial t}= & (1-\gamma) \alpha g_{s} S(P+M)(1-f)+(1-\alpha \gamma) g_{m} M \frac{P}{K_{p}+P} \\
& -\mu \frac{I}{K_{1}+I} P \frac{N}{K_{n}+N}+d_{m} M+\frac{\partial k}{\partial z} \frac{\partial N}{\partial z}
\end{aligned}
$$

where $P, S, M$, and $N$, are phytoplankton, salp, microzooplankton, and nutrient mass concentrations ( $\mu \mathrm{mol}$ $\left.\mathrm{N}^{-1}\right) ; k$ is diffusivity; $t$ is time; $\mu$ and $g_{m}$ are the maximal mass-specific rates of phytoplankton growth and microzooplankton ingestion $\left(\mathrm{d}^{-1}\right) ; f$ is the salp clogging function; $d_{m}$ and $d_{s}$ are mass-specific death rates $\left(\mathrm{d}^{-1}\right)$ of microzooplankton and salps; $e$ is the massspecific death rate $\left(\mathrm{d}^{-1}\right)$ of salps due to starvation after clogging $g_{s}$ is the salp filtration rate $\left(1 \mu \mathrm{mol} \mathrm{N}^{-1} \mathrm{~d}^{-1}\right) ; \alpha$ and $\gamma$ are efficiencies of zooplankton assimilation and net growth; $K_{n}, K_{i}$, and $K_{p}$ are half-saturation constants for nutrient uptake, light utilization, and microzooplankton grazing; $I$ is light at depth $z$ relative to the surface intensity. I decayed exponentially with depth, with the rate of decay proportional to the phytoplankton concentration as given by:

$$
I=\exp \left[-k_{w}-k_{p} \int_{-z}^{0} P(h) \mathrm{d} h\right]
$$

where $k_{w}$ and $k_{p}$ are extinction coefficients due to seawater and phytoplankton, and $h$ is a dummy variable for integration. The salp clogging function, $f$, has a value of zero at concentrations of $P+M$ just below the clogging concentration, $C$, and a value of 1 at concentrations just above $C$, as given by:

$$
f=0.5\left[1+\operatorname{erf}\left(\frac{P+M-C}{10}\right)\right]
$$

where erf is the error function (Hildebrand 1976). The model was run with and without vertical diffusion. When invoked, diffusivity, $k$, varied with depth according to

$$
k=0.5\left[1+\operatorname{erf}\left(\frac{z_{m}-z}{4}\right)\right] k_{1}+k_{0}
$$

where $k_{0}$ is diffusivity below the pycnocline, $k_{1}+k_{0}$ is the diffusivity in the mixed layer, and $z_{m}$ is the middepth of the pycnocline ( $z$ is positive downwards).

By design, the above equations do not conserve total $N$. Losses of $N$ were assumed to occur from rapid sinking of salp faeces and dead bodies such that the loss rate is given by:

$$
d_{s} S+e S f+(1-\alpha) g_{s} S(P+M)(1-f)
$$

To simulate rapid sinking and bottom remineralization of salp faeces and dead bodies, this loss term was added back in to the nutrient pool at the bottom grid point of the model. Thus, total $\mathrm{N}$ was conserved. Nutrients accumulating in the bottom pool were transported vertically via diffusion. The model was solved using a fourth-order Runge-Kutta scheme for the biology and a fully implicit method with no-flux boundary conditions for the physics (Roache 1982)

Parameter values were chosen to approximate conditions in the Hauraki Gulf. Phytoplankton grow at 1 to 2 doublings $\mathrm{d}^{-1}$ in maximal light and nutrients $(\mu=$ $\left.1.0 \mathrm{~d}^{-1}\right)$, and the half-saturation constant for nutrient uptake, $K_{n}$, was $1 \mu \mathrm{mol} \mathrm{N} l^{-1}$ (Parsons et al. 1988). The half-saturation constant for light, $K_{i}$, was 0.2 (Harrison et al. 1985), which gives half-maximal growth rate at $20 \%$ of surface light intensity. Values used for light extinction coefficients ranged between 0.0 and 0.06 $\mathrm{m}^{-1}$ for $k_{w}$ and between 0.02 and $0.066 \mathrm{~m}^{-1} \mu \mathrm{mol} \mathrm{N}-1$ for $k_{p}$. The higher values were obtained from a linear approximation to an equation relating the light extinction coefficient to chlorophyll concentration (Parsons et al. 1988). Microzooplankton ingested a maximum of 2 to 3 times their weight $\mathrm{d}^{-1}\left(g_{m}=1 \mathrm{~d}^{-1}\right)$ and the half-sat-

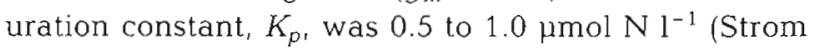
1991). Microzooplankton assimilated $70 \%$ of that ingested ( $\alpha=0.7$; Landry et al. 1984), and salps assimilated $50 \%$ of that ingested (Andersen 1986). A gross growth efficiency of $40 \%$ was assumed for micro- 
zooplankton (Jonsson 1986, Caron \& Goldman 1990) yielding a net growth efficiency of $60 \%(\gamma=0.6)$. Salp filtration rate, $g_{s}$, was calculated to be 0.5 to $2.01 \mu \mathrm{mol}$ $\mathrm{N}^{-1} \mathrm{~d}^{-1}$ from values for Thalia democratica grazing on Isochrysis spp. given in Deibel (1982) using Isochrysis spp. cell volume/nitrogen ratios from Davis (1983), and a value of $g_{s}=0.7$ was used here, yielding a net growth efficiency of $60 \%$. A salp clogging concentration, $C$, of $4 \mu \mathrm{mol} \mathrm{N} \mathrm{l}^{-1}$ was calculated from Harbison et al. (1986) using cell volume/N conversions from Davis (1983). Death rate for microzooplankton, $d_{m}$, was 0.1 to $0.3 \mathrm{~d}^{-1}$ (Gifford \& Dagg 1991). Salp death rate, $d_{s}$, was 0.1 to $0.3 \mathrm{~d}^{-1}$ (Heron \& Benham 1985, Andersen \& Nival 1988). Additional salp death rate due to clogging was assumed to be high ( $e=0.5 \mathrm{~d}^{-1}$; Harbison et al. 1986). When vertical diffusion was invoked, various diffusivity values used were 50 to $100 \mathrm{~m}^{2} \mathrm{~d}^{-1}$ for $k_{1}$ and 2.5 to $10 \mathrm{~m}^{2} \mathrm{~d}^{-1}$ for $k_{0}$ (Jamart et al. 1977, Eppley et al. 1979, King \& Devol 1979, Andersen \& Nival 1988, Davis et al. 1991, Parker 1991). Mixed layer depth, $Z_{m}$, was chosen to be $15 \mathrm{~m}$, approximating the field data.

To examine the relative impact of salp grazing, 2 initial conditions were used. The model was run either without salps or with a small initial inoculum. Other initial conditions and parameter values were the same in both cases and approximated the winter condition in the Hauraki Gulf of high nutrients and lower plankton concentrations. Initial values with and without salps were: $N=2.9, P=1.0, M=1.0, S=0.1$, and $N=3.0, P=$ $1,0, M=1.0, S=0 \mu \mathrm{mol} \mathrm{N}^{-1}$. The model was run for $90 \mathrm{~d}$ to correspond to the observational period in each year of the field program.

\section{RESULTS}

\section{Vertical distribution and abundance of chl a relative to water column structure}

In the first $2 \mathrm{yr}$, chl a concentration (expressed as nitrogen) increased from November to December and then decreased in January (Fig. 3). In the third year, chl a concentration decreased steadily from November to January. Chl a was more abundant below the mixed layer than in the mixed layer in the first 2 yr (Fig. 3), whereas in the third year it was more abundant in the mixed layer than below it [the bottom of the mixed layer, or top of the pycnocline, was defined as the midpoint of the shallowest $5 \mathrm{~m}$ vertical interval in which density (sigma- $t$ ) changed by more than 0.1 unit). The grid-averaged depths of the chl a maxima (Fig. 4a) were consistently well below the mixed layer (Fig 4 b) in the first 2 yr (by 15.9 and $10.6 \mathrm{~m}$, averaged across the respective years), whereas in the third year, they were nearly congruent with the top of the pycnocline $10.6 \mathrm{~m}$
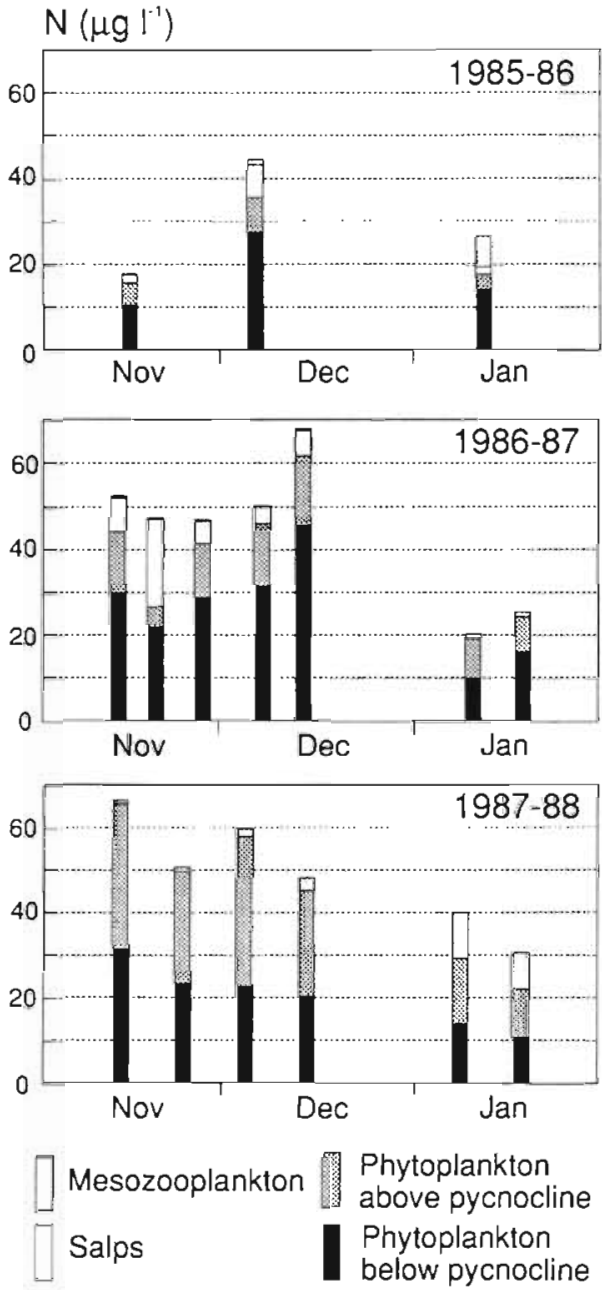

Fig. 3. Abundance of phytoplankton labove and below the pycnocline) and salps and other mesozooplankton (integrated over the water column), as nitrogen ( $\mathrm{Ng}^{-1}$ ), for each grid survey during the $3 \mathrm{yr}$

above it, on average). The depths of the chl a maxima followed the bottom contours in the first 2 yr (Fig. $5 a, b$; compare with Fig. 1), whereas in the third year, the chl a maxima formed a layer at a much more consistent depth over the Gulf (Fig. 5c). Coefficients $\left(r^{2}\right)$ for the correlations of the depths of the chl a maximum layers with the depth of the bottom, averaged over each of the 3 years, were $0.57,0.43$ and 0.13 , respectively. In the first $2 \mathrm{yr}$, the chl a maxima usually occurred near the $1 \%$ light level, or the compensation depth (indicated by the tripled secchi depths in Fig. $5 d$; see Parsons et al. 1988, p. 97). In contrast, the maxima of the third year occurred near the 10\% light level (one-half the tripled secchi depths).

In contrast to the variation in vertical distribution of chl a there was little variation among the years in the grid-averaged depths of the mixed layer (Fig. 4b) and 
intensity of stratification (Fig. 4c; the high stratification in January 1986 was caused by very heavy rainfall).

\section{Abundance and distribution of salps and other mesozooplankton}

In November and December of the first $2 \mathrm{yr}$, large amounts of nitrogen were tied up in salps, with respect to all other mesozooplankton biomass (Fig. 3). Salps were very rare within the grid area in the third year. In mid-November of the first year, the bloom was composed mainly of Salpa fusiformis. In December and January the bloom was composed exclusively of Thalia democratica. In the second year, the blooms were exclusively $T$. democratica. Few depth-stratified mesozooplankton samples were taken where salps were abundant, because sites for depth-stratified sampling
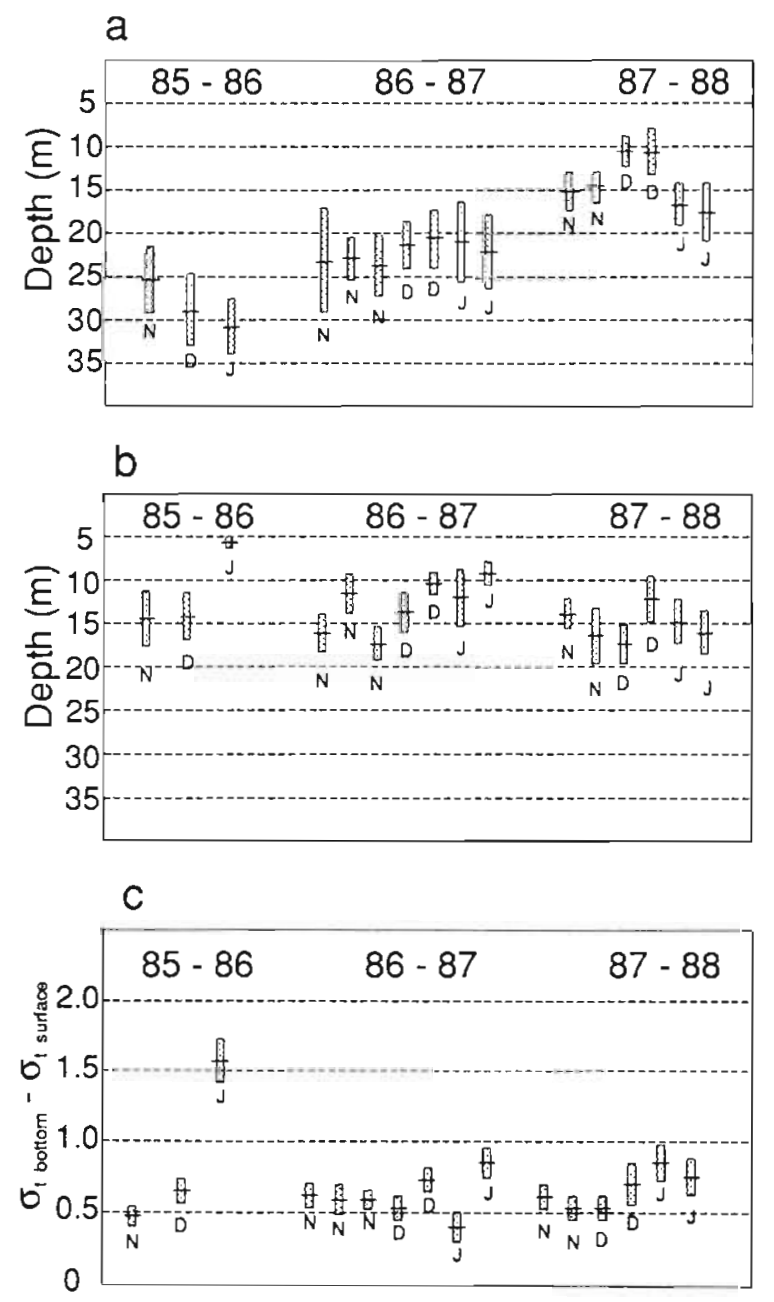

Fig. 4. (a) Depth of the chl a maxima; (b) depth of bottom of mixed layer; (c) difference between bottom and surface density, all averaged over each grid survey in the $3 \mathrm{yr}$ (1985 to 1988). Error bars are $95 \%$ confidence intervals (CI)
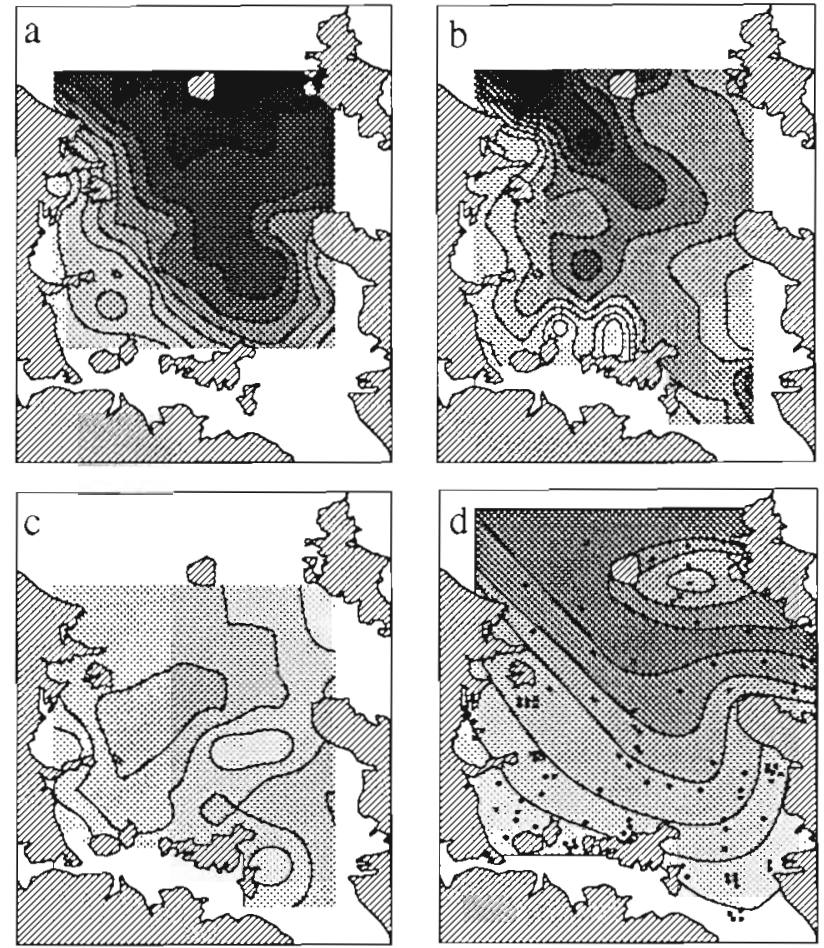

Fig. 5. (a to c) Depths of the chl a maxima for grids done in early December in the $3 \mathrm{yr}_{\text {; }}$ (d) tripled secchi depth (adapted from Paul 1968). Depths increase (from light to dark contours) from $0 \mathrm{~m}$ in steps of $5 \mathrm{~m}$

were chosen where larval snapper were common, and these fish larvae were almost always absent in the vicinity of high salp concentrations. In the 8 depthstratified profiles that did catch salps, they were found throughout the water column, but in 7 of these, they were less abundant near the bottom (Table 1). Salp swarms were often visible at the surface (Zeldis pers. obs.) and were distributed in patches across the Gulf Similar depth distributions of $T$. democratica were found by Paffenhöfer \& Lee (1987) on the southeastern USA continental shelf.

\section{Phytoplankton species composition}

Phytoplankton species compositions (Fig. 6) and taxonomic group proportions (Table 2) differed, particularly between the first 2 years and the third year. This pattern was present in both the clustering analysis (not shown) and ordination analysis. The deep chl a maxima below the mixed layer of the first 2 yr were dominated by diatoms (primarily Thalassiosira sp., Dytilum brightwellii and Rhizosolenia shrubsolei), relative to dinoflagellates and flagellates, while in the third year a more even mixture of diatoms and dinoflagellates (pri- 
Table 1 Volumes of salps caught $\left(\mathrm{ml} \mathrm{m}^{-3}\right)$ at different depths (m) at stations in the Hauraki Gulf. The deepest sample at each station was near the bottom

\begin{tabular}{|c|c|c|c|}
\hline Depth & Volume & Depth & Volume \\
\hline \multicolumn{2}{|c|}{ December 1985} & \multicolumn{2}{|c|}{ December 1986} \\
\hline 10 & 0.96 & 1 & 14.4 \\
\hline 25 & 40.7 & 10 & 5.6 \\
\hline 39 & 0 & 20 & 3.5 \\
\hline 10 & 12.4 & 1 & 2.6 \\
\hline 25 & 0.7 & 10 & 3.8 \\
\hline 44 & 13.2 & 19 & 1.5 \\
\hline 10 & 9 & 1 & 3.4 \\
\hline 25 & 20.6 & 5 & 25.7 \\
\hline 46 & 0 & 10 & 3.8 \\
\hline \multicolumn{2}{|c|}{ November 1986} & 1 & 10.3 \\
\hline 1 & 13.4 & 5 & 5.8 \\
\hline 15 & 20.6 & 10 & 3.4 \\
\hline 29 & 0.3 & 15 & 1.7 \\
\hline
\end{tabular}

marily Rhizosolenia alata, Prorocentrum micans and Distephanum speculum) occurred, both in and below the mixed layer. The ratio of diatom to total phytoplankton carbon was positively correlated $(p<0.001)$ with depth in November and December of the second year, with the predicted proportion of carbon in diatoms equal to 0.49 at the surface and 0.73 at $30 \mathrm{~m}$. This relationship was non-significant $(p=0.54)$ in the

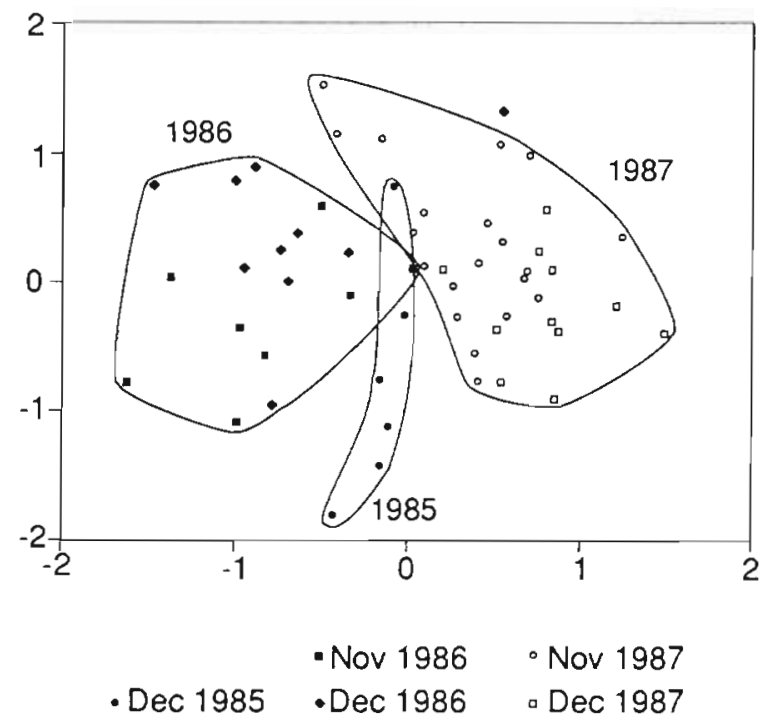

Fig. 6. Phytoplankton species composition differences between years, shown as ordination of phytoplankton samples in 2 dimensions, using multidimentional scaling. Distances separating samples in this plot are proportional to their dissimilarity. Samples from the $3 \mathrm{yr}$ are enclosed by polygons. except for 1 December 1986 sample third year, and the proportion of diatoms was 0.40 , averaged over all depths. There were too few data from the first year at shallow depths to allow this analysis (Table 2), although the proportion diatoms was high at deeper depths, similar to the second year.

\section{Salp grazing rates vs phytoplankton production rates}

The time required by Thalia democratica to clear their resident water volume of phytoplankton was compared with rates that phytoplankton were replacing themselves through primary production. This was done using a literature value of the carbon weightspecific filtration rate for $T$. democratica $\left(0.5 \mathrm{ml} \mu \mathrm{g} \mathrm{C}^{-1}\right.$ salp $\mathrm{h}^{-1}$; Deibel 1985b), and a salp wet weight to carbon weight ratio $(272: 1$; Curl 1961) to convert weights (volumes) of salp samples to carbon weight. It was estimated that a concentration of salps of $8.0 \mathrm{ml} \mathrm{salps} \mathrm{m}^{-3}$ would clear their resident water volume of particles in $2.8 \mathrm{~d}$. The replacement (doubling) times of the phytoplankton communities were estimated using primary production estimates made in November 1985 and November 1986. It was assumed that the $\mathrm{C}$ : chl a ratio was 100 (see 'Discussion') and that the phytoplankton photosynthesized for $12 \mathrm{~h}$ each day, In November 1985, using production estimates from 24 stations, a mean assimilation ratio ( $\mu \mathrm{g} \mathrm{C}$ fixed $\mathrm{h}^{-1} \mu \mathrm{g}^{-1} \mathrm{chl}$ a) of 4.0 was estimated, and it was calculated that the phytoplankton doubled in $100 /(4.0)(0.5)=50.0 \mathrm{~h}$ or 2.1 d. In November 1986, using samples from 6 stations, a mean assimilation ratio of 2.6 was estimated, producing a doubling time of $3.2 \mathrm{~d}$. Thus, the time $8.0 \mathrm{ml}$ salps $\mathrm{m}^{-3}$ would take to clear their resident water volume of particles ( $2.8 \mathrm{~d}$ ) was similar to the doubling times of the phytoplankton, suggesting that this salp concentration or greater would be capable of overtaking the phytoplankton population growth rate

Table 2. Mean proportion of total phytoplankton carbon (1 $\mathrm{SE}$ ) in and below the mixed layer, in diatoms (Dia.), dinoflagellates (Din.) and flagellates (Fla.), by year. N: number of samples

\begin{tabular}{|lcccr|}
\hline & Dia. & Din. & Fla. & N \\
\cline { 1 - 4 } Dec 1985 & & & & \\
In mixed layer & $0.39(0.01)$ & $0.47(0.06)$ & $0.14(0.07)$ & 2 \\
Below mixed layer & $0.69(0.09)$ & $0.24(0.08)$ & $0.07(0.03)$ & 10 \\
Nov-Dec 1986 & & & & \\
In mixed layer & $0.57(0.08)$ & $0.21(0.06)$ & $0.22(0.05)$ & 10 \\
Below mixed layer & $0.72(0.05)$ & $0.14(0.03)$ & $0.14(0.04)$ & 18 \\
Nov-Dec 1987 & & & & \\
In mixed layer & $0.43(0.05)$ & $0.36(0.04)$ & $0.21(0.04)$ & 19 \\
Below mixed layer & $0.39(0.04)$ & $0.41(0.05)$ & $0.20(0.03)$ & 21 \\
\hline
\end{tabular}


and reducing phytoplankton biomass directly. This salp concentration was near the average value found across the grids (it corresponds to $6.64 \mu \mathrm{g} \operatorname{salp~} \mathrm{N}^{-1}$; see Fig. 3) showing that on average salp grazing rates and phytoplankton growth rates were in equilibrium. However, at many sites salp concentrations were $>8 \mathrm{ml}$ salps $\mathrm{m}^{-3}$, and there salps and phytoplankton would have been in disequilibrium, with phytoplankton biomass declining through grazing pressure.

\section{Correlations of salp and chl a abundance}

There was a strong negative correlation of chl a and salp concentrations, averaged across all stations for surveys which had salps (Table 3 ). The absolute amount of reduction of chl $a$ in the presence of salps was similar in the mixed and stratified layers (explaining the lack of a significant interaction in the analysis of variance; Table 3). However, the relative amount of chl a reduction between the different salp concentrations was greater in the mixed layer than in the stratified layer. The absolute chl a reduction was similar for moderate $(\geq 1$ to $<8)$ and high $\left(\geq 8 \mathrm{ml} \mathrm{m}^{-3}\right)$ salp concentrations, even though moderate salp concentrations were less than those calculated to outstrip phytoplankton growth rates (see previous section). This similarity suggested that salps were limiting phytoplankton biomass in ways more complex than by simply slowing its population growth rate.

This was studied further by examining temporal and spatial relationships of chl a and salps for the first 2 yr (Fig. 7b, c). Nitrate data were also available for the first year (Fig. 7a). In mid-November, nitrate was in limiting concentrations $\left(<7 \mu \mathrm{g} \quad \mathrm{N} \mathrm{l}^{-1}\right.$ or $0.5 \mu \mathrm{mol} \mathrm{N} \mathrm{l}{ }^{-1}$; Eppley et al. 1979) throughout the inner Gulf. However, nitrate was nonlimiting in the northwest and higher chl a was found there (Fig. 7b), in the presence of low to moderate salp biomass. In the centraleastern Gulf lower chl a was associated with moderate to high salp biomass. In early December, nitrate had increased in the northern Gulf, and a bloom of chl a formed there. Salp biomass was generally low in the bloom area. Salps had proliferated over most of the central Gulf, and were associated with low chl a. Salps were less common in the southern Gulf and chl a was higher there (note the southern vertical section). In mid-January, nitrate was abundant in the northwest. Regardless, a chl a minimum had formed throughout the water column there, and salps were abundant. Chl a was distributed in deep maxima over most of the Gulf, except in the southernmost transect where salps had been rare since early December.

From early to mid-November of the second year (Fig. 7c) salp biomass increased to high levels at most stations over the Gulf. Average chl a concentration declined in mid-November, especially in the upper water column (Fig. 3), and chl a was concentrated near the bottom at stations where salps were abundant. By late November, salp biomass had started to wane, but at most stations mixed and stratified layer chl a concentration remained low, except for a bloom in the northern Gulf where salp biomass was low. In early December, salp biomass continued to decline at most stations, but it was still high in the central-western Gulf and chl a there had dropped to very low levels $\left(<0.5 \mu \mathrm{g} \mathrm{chl} \mathrm{a}^{-1}\right)$ throughout the water column. Salps had proliferated in the northwest, in the area of the chl a bloom of late November, and chl a there had declined. In the eastern and southern Gulf, however, chl a was starting to shoal and form a midwater maximum, where salp concentrations had been low since late November. By mid-December, salp concentrations were low at many stations and chl a concentrations increased dramatically in the stratified layer and shoaled toward the mixed layer over a wide area of the Gulf. Salps were still common in the central-western area, and there chl $a$ in the upper water column remained low. In the eastern Gulf salp concentrations had become low or zero and a midwater chl a maximum persisted. In the southern Gulf salps had prolifer-

Table 3. Effects of sample depth and salp concentration on chl a concentration tested by analysis of variance (ANOVA). Treatment levels for depth were: in or below the mixed layer; levels for salp concentration were: low $(<1)$, moderate $(\geq 1$ to $<8)$, or high $\left(\geq 8 \mathrm{ml}\right.$ salps $\left.\mathrm{m}^{-3}\right)$. Data were from all stations in grids which had salps in the first 2 yr. Data were $\log (x+1)$-transformed prior to ANOVA. Data were still heterogeneous after transformation (Cochrane's $C=0.232$, with $C_{\mathrm{cnl}}=0.212$ ), but since main effects were very highly significant, the analysis is considered robust. Chl a means ( $\mathrm{gg} \mathrm{l}^{-1}$ ) and standard errors at each treatment level are arithmetic

\begin{tabular}{|c|c|c|c|c|c|}
\hline Treatment & SS & df & MS & Ratio & $\mathrm{p}$ \\
\hline Depth & 79.904 & 1 & 79.904 & 296.770 & $<0.001$ \\
\hline Salps & 23.676 & 2 & 11.838 & 43.966 & $<0.001$ \\
\hline Depth $\times$ Salps & 0.143 & 2 & 0.072 & 0.266 & 0.767 \\
\hline Error & 388.793 & 1444 & 0.269 & & \\
\hline \multicolumn{3}{|c|}{ Treatment levels } & Mean chl $a$ & SE & $\mathrm{N}$ \\
\hline \multicolumn{3}{|c|}{ In mixed layer, low salps } & 1.12 & 0.10 & 299 \\
\hline \multicolumn{3}{|c|}{ In mixed layer, moderate salps } & 0.54 & 0.14 & 155 \\
\hline \multicolumn{3}{|c|}{ In mixed layer, high salps } & 0.64 & 0.12 & 195 \\
\hline \multicolumn{3}{|c|}{ Below mixed layer, low salps } & 2.62 & 0.09 & 384 \\
\hline \multicolumn{3}{|c|}{ Below mixed layer, moderate salps } & 1.83 & 0.12 & 202 \\
\hline \multicolumn{3}{|c|}{ Below mixed layer, high salps } & 1.80 & 0.12 & 215 \\
\hline
\end{tabular}


a. $1985-86$ nitrate
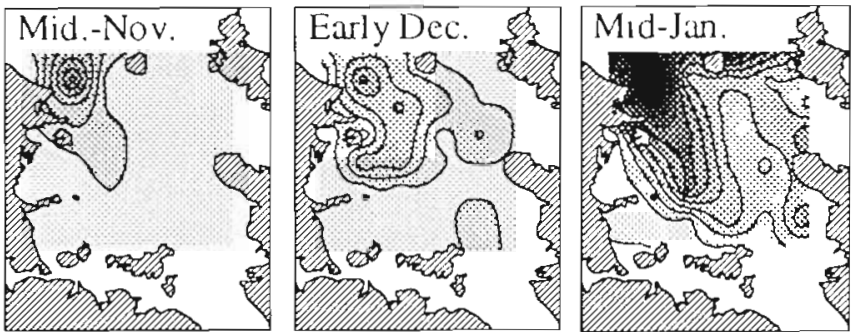

b. $1985-86 \mathrm{chl}$ a and salps
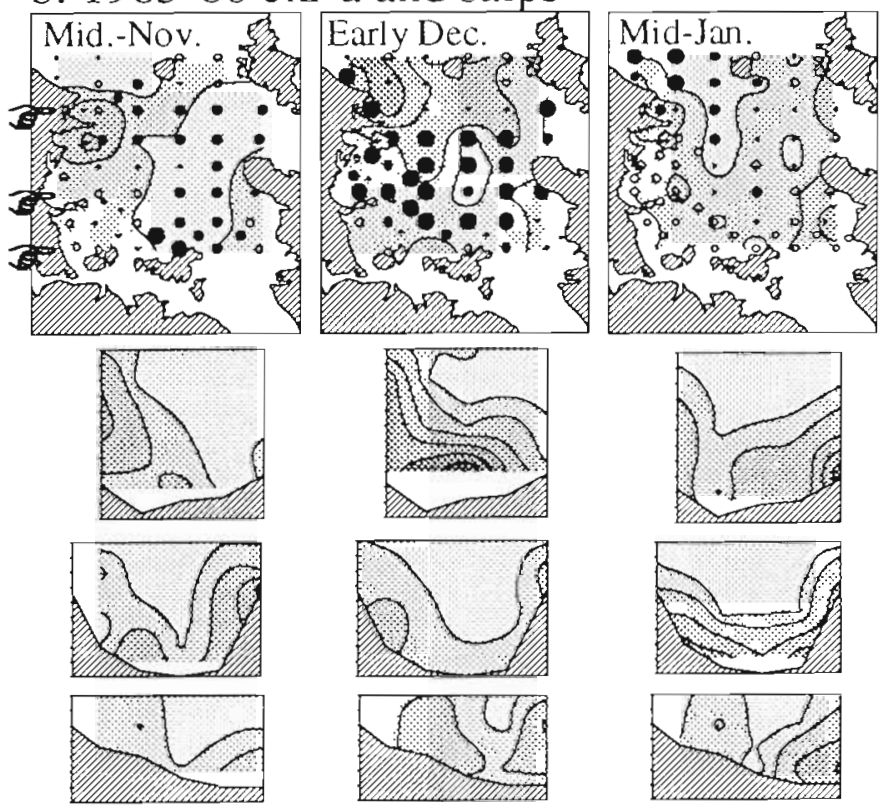
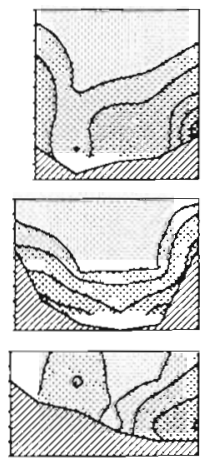

Fig 7 (a) Nitrate concentrations from November to January 1985-86. Concentrations are water-column means, contoured honzontally, and increasing (from light to dark contours) from $0 \mu \mathrm{g} \mathrm{N} \mathrm{I}^{-1}$ in steps of $5 \mu \mathrm{g} \mathrm{Nl}^{-1}$ (b) Chl a and salp concentrations from November to January 1985-86 Chl a concentrations are water column means, contoured horizontally, and increasing (from light to dark contours) in steps of 0.5 to $1.0 \mu \mathrm{g} \mathrm{l}^{-1}$, and then in steps of $10 \mu \mathrm{g}{ }^{1} \mathrm{Chl}$ a is also contoured in 3 vertical sections for each gnd (section locations indicated on the first horizontal chl a plot) Depth increments are $5 \mathrm{~m}$. Salp concentratrons shown as circles on the horizontal chl a plots. An open circle is zero salps and small, medium and large solud curcles are $<1, \geq 1$ to $<8$, and $\geq 8 \mathrm{ml}$ salps $\mathrm{m}^{-3}$. indicating low, moderate and high salp concentrations, respectuvely (c) Chl $a$ and salp concentrations from November to December 1986. Chl a contour and salp circle values as in (b) Equipment failure in early November 1986 caused loss of chI a data from all western Gulf stations, except for western stations on the 2 southern vertical sections c. $1986 \mathrm{chl}$ a and salps
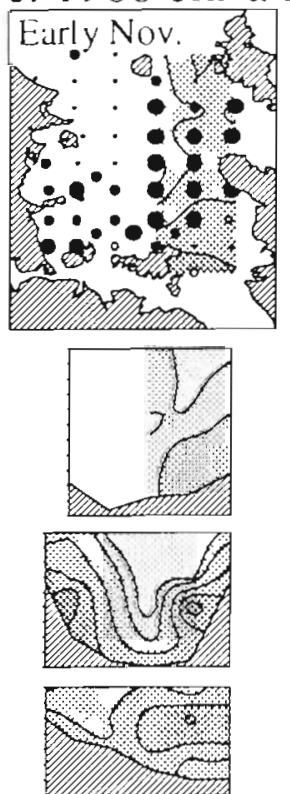
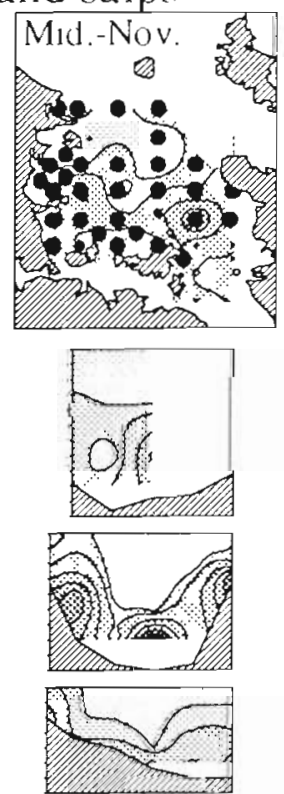
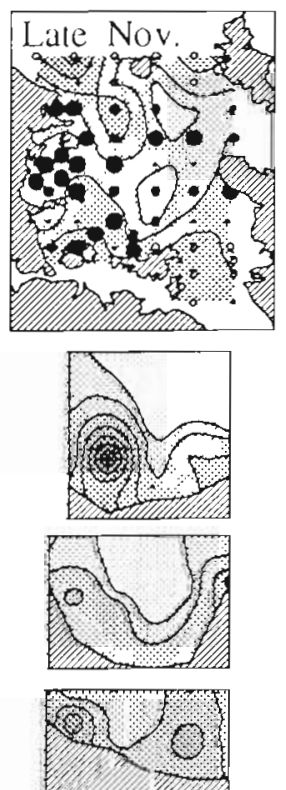
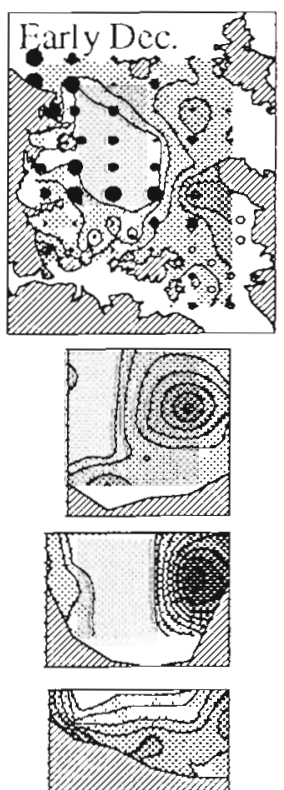
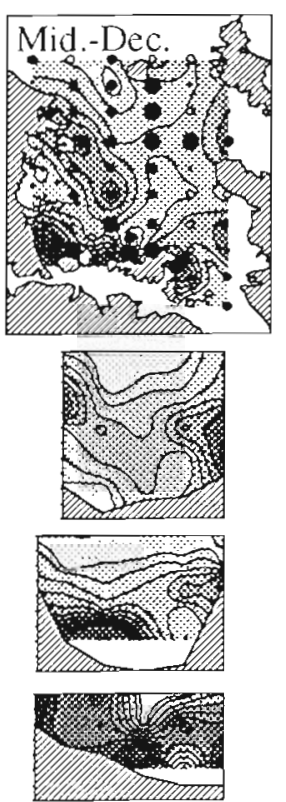
ated for a second time, in an area where chl a concentration was high and concentrated near the bottom.

Although nutrient samples were not collected in the second year, the formation of a chl a bloom in the northern Gulf in late November 1986 (Fig. 7c) suggests that nitrate distribution may have been qualitatively similar to that measured in early December 1985 (Fig. 7b). Again, however, it appeared that this nitrate was effective in stimulating chl a increase only if salps were absent from the water mass. When salps proliferated in the area in early December 1986 (Fig. 7c) chl a concentration became low. Thus, it appeared that salps were effective in reducing chl a concentrations independently of nutrient concentration. The detailed time series of the second year showed that, following reduction and deepening of chl a during and after a salp bloom, chl a increased and shoaled toward the mixed layer as salp biomass declined. However, this shoaling was a slow process, occurring over 2 to 3 wk from the middle to the end of the time series, often well after salps had dissipated. This could explain why low chl a was often correlated with only moderate salp biomass (Table 3). The mechanism by which salp grazing could generate this 'lagged response' in the phytoplankton is investigated below.

\section{Nutrient-phytoplankton-zooplankton model and resuspension calculations}

The N-P-Z model was used to investigate whether different grazing regimes could have caused the variation in phytoplankton biomass and vertical distribution observed between years with and without salps. When microzooplankton were the only grazers, phytoplankton concentration was higher in the upper water column throughout the model run. An equilibrium was reached after $30 \mathrm{~d}$ (Fig. 8a), in which phytoplankton concentrations ranged from $25 \mu \mathrm{g} \mathrm{N}^{-1}$ at the bottom to $40 \mu \mathrm{g} \mathrm{N}^{-1}$ at the surface. In this case, microzooplankton concentration was also higher toward the surface, whereas nutrient concentration increased with depth. In the salp case, the initially small inoculum of salps grew rapidly and high surface salp concentrations quickly grazed down the phytoplankton bloom and caused rapid accumulation of nutrients in the bottom pool through production of sinking faeces and salp carcasses. After 30 d (Fig. 8b), a steady state was reached in which phytoplankton concentrations were higher in the lower part of the water column. Salp and especially nutrient concentrations were also higher in the lower part of the water column.

The vertical distributions of phytoplankton and nutrients in the field closely matched modelled distributions of these variables (Figs. 3, 5, 7 \& 9). Modelled
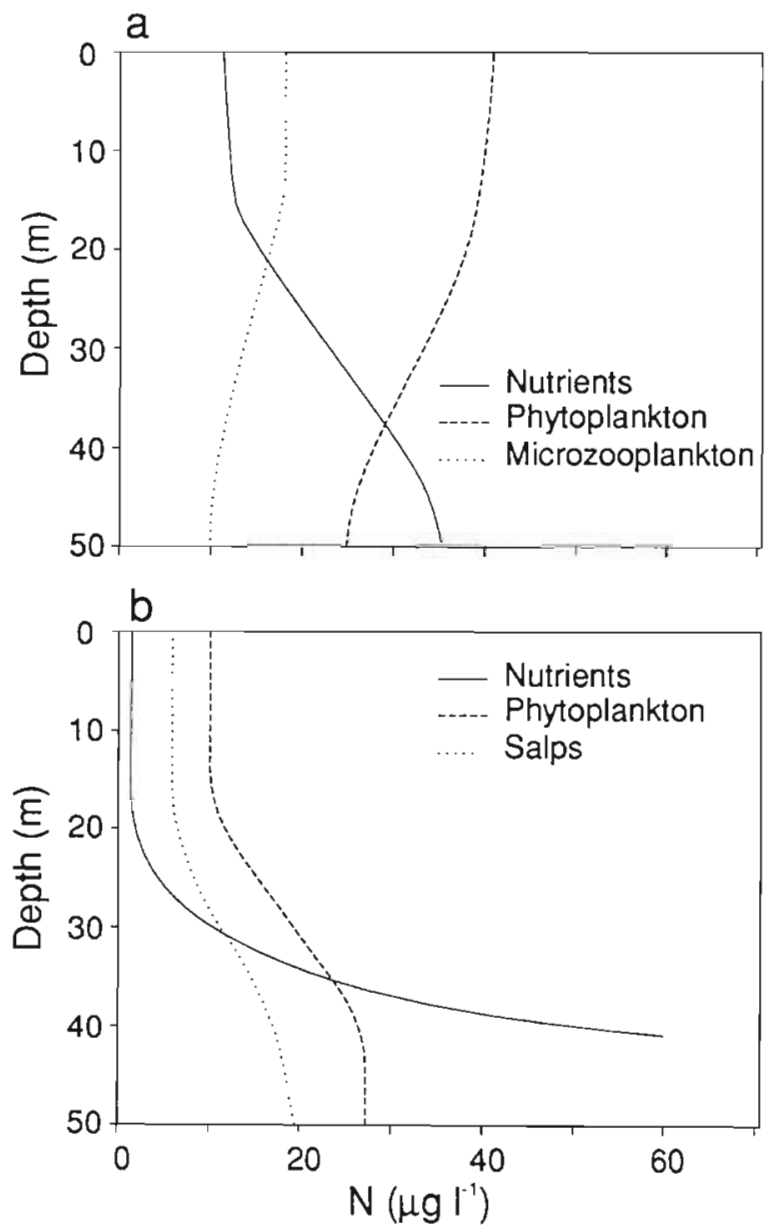

Fig. 8. Nutrient-phytoplankton-zooplankton (N-P-Z) model results. Vertical distributions of nutrients (continuous line), phytoplankton (dashed line) and (a) microzooplankton or (b) salps (dotted line) shown in $\mu \mathrm{g} \mathrm{N} l^{-1}$

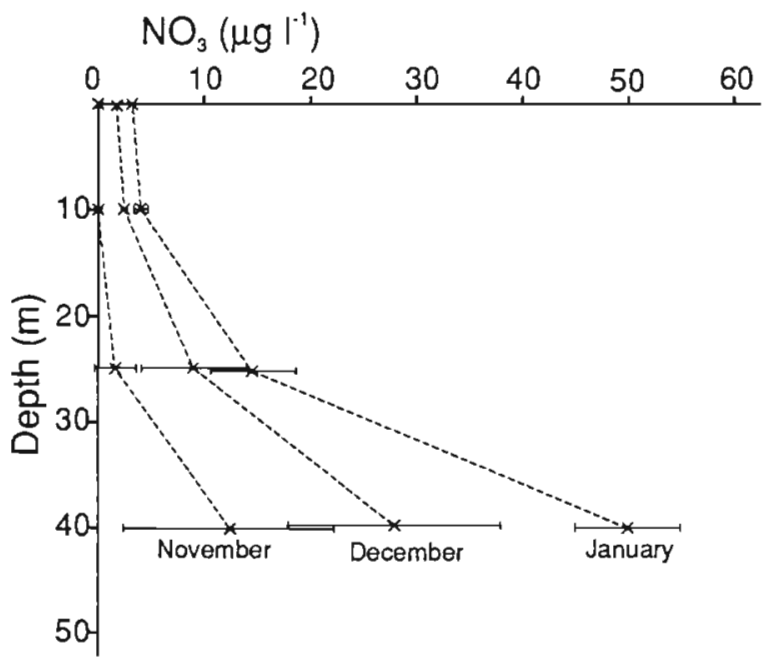

Fig. 9. Average nitrate concentrations ( $\mu \mathrm{g} \mathrm{l}^{-1}$ ) across the grids done in November, December and January 1985-86, by depth. Error bars are $95 \%$ CI 
depth-averaged salp concentrations were close to those observed in the field (Fig. 3). However, the limited field observations of salp vertical distribution (Table 1) suggested salps were uniformly distributed or perhaps less abundant near the bottom, whereas the steady-state population in the model was more abundant in the lower half of the water column. The modelled salp population, however, reached highest concentration in the mixed layer during the first $30 \mathrm{~d}$ (not shown) and only after grazing down the phytoplankton in this layer did the salps distribution shift to the lower half of the water column. It is likely that the observed field populations of salps were in various dynamical states and could have had various vertical distributions.

The nutrient distributions and effects of salp grazing in the model could be expected to be sensitive to the value of the pycnocline vertical diffusivity constant $\left(k_{0}\right)$ used, because this term determines the rate of resuspension of remineralized $N$ from salp faeces and carcasses from the bottom back toward the mixed layer. However, the results of Fig. $8 \mathrm{~b}$ were essentially insensitive to the $k_{0}$ value used, when tested over a reasonable range $\left(k_{0}=2.5\right.$ to $10 \mathrm{~m}^{2} \mathrm{~d}^{-1}$; Jamart et al. 1977 , Eppley et al. 1979, King \& Devol 1979, Parker 1991). To examine the reason for this, this range of diffusivity constants and the nitrate profiles obtained in 1985-86 (Fig. 9) were used to estimate the rate at which nitrate was diffusing up the pycnocline using the diffusion equation:

$$
\frac{\partial c}{\partial t}=-k_{0} \frac{\partial^{2} c}{\partial z^{2}}
$$

where $c$ is nitrate concentration $\left(\mu \mathrm{g} \mathrm{l}^{-1}\right), t$ is time (s) and $z$ is depth $(\mathrm{m})$. The diffusion rates, $\partial c / \partial z$, above and below $25 \mathrm{~m}$, were approximated by $\Delta c / \Delta z$ between 10 and $25 \mathrm{~m}$ and 25 and $40 \mathrm{~m}$. The difference in these was taken at $25 \mathrm{~m}$ to approximate $\partial^{2} \mathrm{c} / \partial z^{2}$. Using the December 1985 nitrate profile and the $k_{0}$ values from 2.5 to $10 \mathrm{~m}^{2} \mathrm{~d}^{-1}$, the upward diffusion rates ranged

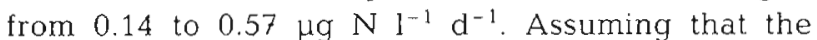
$C$ : chl a ratio was 100 and the $C: N$ ratio was 15 (such as might obtain in nutrient deficient waters - see 'Discussion'), a mixed layer phytoplankton concentration

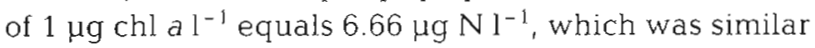
to the minimal mixed layer values observed (Fig. 3).

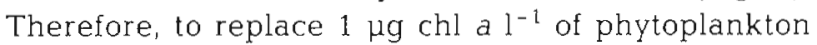
using 'new' nitrogen from below the mixed layer would take between $6.66 / 0.14=48 \mathrm{~d}$ and $6.66 / 0.57=$ $12 \mathrm{~d}$. Since $8 \mathrm{ml}$ salps $\mathrm{m}^{-3}$ would clear the water of this phytoplankton in $2.8 \mathrm{~d}$, it is clear why the N-P-Z results were insensitive to $k_{0}$, and how the modelled biological dynamics easily dominated the effects of vertical mixing.

\section{DISCUSSION}

The results indicate that in the coastal environment, salp blooms can reduce phytoplankton biomass and deepen its distribution because of incorporation of nitrogen into salp biomass and the deposition of nitrogen in salp faeces and carcasses onto the bottom or into near-bottom waters. This nitrogen is not lost from the photic environment because of the shallow depths, but because it is slow to recirculate up the pycnocline and into the mixed layer, the deep phytoplankton biomass maximum persists, even at sites where salp biomass is no longer high. When salp blooms are absent, there is less waste material overall and more of it is remineralized in the mixed layer, producing higher concentrations of phytoplankton there. The N-P-Z model recreated these conditions using a reasonable set of parameter values derived from the literature. The essential difference between the cases modelled was that microzooplankton faeces and dead bodies were remineralized locally whereas those of salps were remineralized after sedimentation.

Before discussing the results further, a number of assumptions made in this study will be considered. When phytoplankton population production rates were compared with salp population grazing rates it was assumed that the phytoplankton $C$ : chl a ratio was 100 If the true $C$ : chl a ratio was actually less than this (as might occur under non-limiting nutrient conditions; Eppley et al. 1977), the phytoplankton doubling times would have been faster, and higher salp biomasses would have been required to overtake phytoplankton production. However, even if the $C$ : chl a ratio was low, and therefore phytoplankton were growing rapidly, the proposed effects of salps grazing could still occur. This is because, as well as reducing phytoplankton biomass directly through grazing, salp blooms abstract nutrient from the upper water column through the production of large, rapidly sinking faeces, so that initially fast phytoplankton growth is rapidly curtailed. Also, when incorporation rates of nitrogen into phytoplankton and sinking salp faeces were estimated, it was assumed that the $\mathrm{C}: \mathrm{N}$ ratio in phytoplankton was 15 . This is at the upper end of the range for this ratio and is most likely to occur in nutrient-deficient waters (Banse 1974). If the true ratio was lower, the incorporation of nitrogen into phytoplankton and sinking faeces would have been accelerated.

Cullen (1982) reviewed a number of mechanisms for the formation of chl a and phytoplankton vertical distributions in various marine environments, and showed that in some cases fluorescence $(F)$ maxima may form which do not represent chl a maxima because of varying $F$ : chl a ratios with depth. In the first year of the present study all chl a determinations were 
made using in vitro fluorometry (i.e. F:chl a regressions were not used to predict chl a) and therefore the large contrasts between the mixed and stratified layer chl $a$ for that year cannot be attributed to variable $F$ : chl a ratios. For the second and third years, chl a was predicted using regressions between $F$ and extracted chl a for randomly chosen depths across the station grids, so it could be hypothesized that there were differences in the $F$ : chl a ratios with depth that caused mixed layer chl a to be underestimated in the second year or overestimated in the third year. This was tested by comparing the $F$ : chl a ratios (averaged across November, December and January) of the mixed layer and stratified layers, for the second and third years. In the second year, the mean $F$ : chl a ratio ( $\pm 1 \mathrm{SE}$ ) in the mixed layer $(23.19 \pm 1.91)$ was significantly higher $(p>$ $0.01)$ than the mean ratio below the mixed layer $(18.76$ \pm 0.77 ; means compared using the 2 -sample randomization test; Manly 1994). In the third year, the mean $F:$ chl a ratio in the mixed layer $(24.43 \pm 0.64)$ was significantly less $(p>0.05)$ than that below the mixed layer $(26.63 \pm 0.93)$. Therefore, contrary to the above hypothesis, the regressions formed from these data to predict chl a from $F$ would have overestimated mixed layer chl $a$ in the second year, and underestimated it the third year. This shows that the true differences between mixed layer chl a concentrations of the second and third year were actually somewhat larger than measured using fluorescence.

Cullen (1982) also showed that some chl a maxima do not correspond to biomass maxima, because of changes in $\mathrm{C}$ : chl a with depth due to shifts in algal physiology or species composition. This would not have been detected here because $C$ : chl a ratios were not determined and were only assumed. However, other studies show that dinoflagellates typically have 3- to 4 -fold higher $\mathrm{C}$ : $\mathrm{Chl}$ a than diatoms (Chan 1980) such that $C$ : chl a ratios of 100 or more are associated with dinoflagellate-dominated communities, compared with ratios of on the order of 30 in diatom communities (Eppley et al. 1977). The deep phytoplankton layers of the first 2 yr probably had low $\mathrm{C}$ : chl a because they were composed largely of diatoms (Table 2) and may have been depth-adapted, while the mixed layer chl a of the second year had somewhat lower proportions of diatoms and so probably had higher $\mathrm{C}$ : chl a (Table 2; note that the sample number for the mixed layer of the first year was too small for this determination). This suggests that, in terms of biomass, the profiles within the first 2 yr may have been more vertically homogeneous than suggested by chl a. However, when the chl a profiles and taxonomic compositions between the years are compared, it is likely that the phytoplankton biomasses of the third year, particularly in the mixed layer, were considerably higher than in the first 2 yr.
This is because mixed layer chl a in the third year was much more abundant, and it included a somewhat higher proportion of dinoflagellates than the second year (Table 2).

It was assumed that salp faeces and carcasses sank out of the mixed layer to remineralize at depth. The sinking rates of thaliacean faeces vary, and range from 100s of $\mathrm{m} \mathrm{d}^{-1}$ for larger oceanic salps (Bruland \& Silver 1981, Madin 1982, Morris et al. 1988, Deibel 1990) to considerably slower rates for small continental shelf dwelling salps such as Thalia democratica (Pomeroy \& Deibel 1980) and the doliolid Dolioletta gegenbauri (Deibel 1990). For these smaller thaliaceans, the sinking rate appears to depend largely on the quality of the diet. Faeces produced by $D$. gegenbauri, fed a mixture of flagellates, dinoflagellates and diatoms, sank 59 to $405 \mathrm{~m} \mathrm{~d}^{-1}$ (Deibel 1990), similar to observations on this species by Bruland \& Silver (1981). Pomeroy \& Deibel (1980), while noting that faeces of $T$. democratica sank slowly, commented that they 'were most common in sea water samples taken in or below dense populations of salps'. In the present study, salps were feeding on a mixed assemblage of phytoplankton (Table 2), so it is likely that the faeces would have sunk at similar rates to those of the small, coastal thaliaceans noted above. It was also assumed that salp carcasses would have sunk rapidly.

In the N-P-Z model it was assumed that only salp faeces and carcasses sank out of the mixed layer. Although microzooplankton are likely to produce faeces and carcasses that degrade in situ (Harrison 1978, Michaels \& Silver 1988), this assumption is not completely valid for mesozooplankton. However, relatively high biomasses of mesozooplankton (larval and adult herbivorous copepods, brachyuran larvae and cladocera; Zeldis unpubl. data) were present in the third year (Fig. 3), yet the mixed layer did not become impoverished in chl a. Since faecal pellets from herbivorous copepods sink in the laboratory (Small et al. 1979, Deibel 1990) and have been found at depth in the field (Bishop et al. 1977, Fowler et al. 1987), such impoverishment might have been expected. However, in other field studies, copepod faecal pellets were found in quantity only within the mixed layer and did not contribute in large proportion to total carbon flux (e.g. 10 to $19 \%$ of total flux in the upper $150 \mathrm{~m}$ in Urrere \& Knauer 1981, see also Knauer et al. 1979, Krause 1981, Smetacek 1985). Copepod faecal pellets appear to undergo extensive recycling in the mixed layer, through coprophagy (Paffenhöfer \& Knowles 1979). Evidently, copepod faecal pellets do sink from the mixed layer, but often much more slowly than their rate of production (Fortier et al. 1994).

In contrast, there are numerous reports of salp faecal material dominating mass flux in sediment trap collec- 
tions below the mixed layer (Dunbar \& Berger 1981, Iseki 1981, Urrere \& Knauer 1981, Morris et al. 1988, Fortier et al. 1994). Salp faeces occurred in large amounts over short time periods in these collections. In one case discussed by Urrere \& Knauer (1981) faeces from swarm concentrations of Salpa fusiformis were responsible for $90 \%$ of the mass flux in sediment traps. Smetacek (1985) suggested that sinking of salp faecal production can occur in such large quantities over such short time periods (days), that it overwhelms pelagic heterotroph utilization. In this respect it is similar to the seasonal sinking of senescent phytoplankton, a similarity also demonstrated by Michaels \& Silver (1988) in their trophic web model. Considering the very high biomasses of salps observed relative to other mesozooplankton (Fig. 3) in this study, it is suggested that this overwhelming effect occurred and prevented salp faecal material from being retained in the upper water column, even if it sank relatively slowly. This would have led to a progressive buildup of decaying organic material in the deeper layers, either through sedimentation from a single ingestion, or through a 'chain effect' of successive cycles of ingestion, defaecation, sinking and reingestion by salps (note that high salp biomasses were observed at most depths; Table 1). This transfer of material to below the mixed layer or even the bottom would not take long, as the pycnocline was usually located between 10 and $20 \mathrm{~m}$ (Fig. 4b) and the sea bottom was generally less than $50 \mathrm{~m}$ (Fig. 1). Once at depth, Thalia democratica faeces would remineralize within 2 to $3 \mathrm{~d}$ in subtropical conditions (Pomeroy \& Deibel 1980, Pomeroy et al. 1984)

Could the contrasting grazing regimes have caused the differing phytoplankton taxonomic compositions? Diatoms typically have much faster intrinsic growth rates than dinoflagellates or flagellates (on the order of 2- to 4 -foldi Chan 1980, Chisholm \& Brand 1981, Banse 1982 , F. H. Chang unpubl. data), primarily because they have higher photosynthetic capacity per unit biomass (Chan 1980). Where nutrients are plentiful, diatoms can outcompete dinoflagellates and flagellates by virtue of these high maximum growth rates, whereas in waters of low but steady nutrient supply, the reverse can occur (Margalef 1958, Eppley et al. 1977, Turpin \& Harrison 1979, Chan 1980, Hallegraeff 1981). Diatoms dominated the deep chl a maxima of the first 2 yr and these maxima usually occurred near the $1 \%$ light level. This was in the vicinity of the measured nutrient maxima (Fig 9) and nutrient maxima resulting from sedimentation in the N-P-Z model (Fig. 8b). This suggests that diatoms would have been selected when salps were abundant, because they would grow faster in the face of intense grazing pressure, and would be more tolerant of low light levels at depth, where nutrients were sequestered. Evidently, however, the diatoms of these chl a maxima were lightlimited on some occasions by their proximity to the compensation depth (Waite et al. 1992), judging by the very low chl a concentrations observed at depth in the central Gulf in late November and early December of the second year (Fig. 7b), even where salp biomass had dissipated. In contrast, the maxima of the third year had an even mix of diatoms and dinoflagellates. These maxima were centred near the $10 \%$ light level, at which dinoflagellates were shown to aggregate by Cullen \& Eppley (1981). There was no partitioning of phytoplankton taxa by depth in the third year, suggesting that the selection pressure favouring deep, diatom-dominated communities was absent.

If nutrients become depleted in the upper water column, phytoplankton can lose the physiological means to remain buoyant and sink to the nitracline. There, they can form biomass maxima in response to elevated nutrients (Steele \& Yentsch 1960, Cullen \& Eppley 1981, Cullen 1982, Waite et al. 1992). Since mass sinking of phytoplankton is likely to have effects similar to those of salp grazing (removal of phytoplankton biomass and nutrients from the mixed layer), the 2 processes may be confounded in this study. By the former process, the deepened chl a distributions seen in the first 2 yr would have been caused by nutrient depletion and phytoplankton sinking. In the third year, conversely, the shallow, abundant chl a concentrations would have been supported by repeated mixing of nitrate into the mixed layer through the spring and summer. However, this variation in mixing rates was not evident among the 3 years (Fig, 4 b, c). Furthermore, dynamic relationships were observed between salps and chl a (Fig. 7b, c), such that as salps colonized new areas of the Gulf, chl a concentration was often reduced, even in cases where nitrate was evidently plentiful below the mixed layer. When salp abundance declined, a slow increase in chl a concentration and formation of midwater maxima were seen (Fig. 7c), consistent with slow upward mixing of remineralized nutrient. Along with the N-P-Z and resuspension modelling results, these field data suggested that salp grazing had strong effects on phytoplankton biomass and vertical distribution.

The wind-driven, horizontal water mass exchange between the shelf and the Hauraki Gulf was hindcast by Sharples \& Grieg (1993), using the circulation model of Proctor \& Grieg (1989) and the winds that blew in the Gulf region from September to February during the years of this study. Intrusions of shelf water into the Gulf were hindcast for October and November of the the first $2 \mathrm{yr}$. These intrusions were detected in CTD data when sampling started in November of the first 2 yr (Zeldis 1993). Since both Salpa fusiformis and Thalia democratica typically have shelf and slope 
water affiliations (Jillett 1971), this suggests that the salps were injected into the neritic waters of the Gulf by the intrusions and that this occurred well before sampling started in the first $2 \mathrm{yr}$. Thus, it appears that the phytoplankton and salp blooms developed together in the spring. This would support the hypothesis of Fortier et al. (1994) that for salp blooms to form, the salps must proliferate synchronously with the phytoplankton. This allows the salp population to control phytoplankton density and prevents the food from clogging the the salp feeding apparatuses (Harbison et al. 1986). The N-P-Z model was configured on this basis, with both phytoplankton and salps starting at low initial concentrations, using a clogging function to modify death and faecal production rates of salps. In contrast, since copepods are capable of regulating their feeding rate, they can succeed when food levels are high. This may have occurred in the third year, when copepod biomass showed a slow, steady increase within a rich phytoplankton community in which salps were very rare.

These findings contibute to growing evidence (Fortier et al. 1994) that grazing by salps can exert significant 'top down' effects on phytoplankton biomass. However, the effects of salp grazing in nearshore waters appear to be intrinsically different from salp grazing effects in slope and oceanic waters. Bathmann (1988) showed that Salpa fusiformis blooms prematurely ended the spring phytoplankton bloom in Irish slope waters by sedimenting algal cells out of the euphotic zone in faecal pellets. In the present study, the environment was much shallower, and salp grazing effects were not manifested as complete losses of phytoplankton to deep water but as an alteration of phytoplankton biomass, vertical distribution and taxonomic composition within the euphotic zone. Contrary to the comment by Fortier et al. (1994) that salps rarely dominate zooplankton assemblages in coastal and shelf waters, blooms of $S$. fusiformis and Thalia democratica have been observed regularly in nearshore waters in the Hauraki Gulf and east Australia (see 'Introduction'). Since these species are distributed worldwide, it may be that their influence on coastal production patterns is more significant than has been appreciated.

Acknowledgements. We acknowledge Mike Moore for assistance with mixing calculations and Robin Murdoch and Janet Grieve for reviewing the manuscript, all at NIWA. Gary Voss, Jonathan Ingerson and the officers and crew of the NIWA RVs 'James Cook' and 'Kaharoa' provided technical assistance. Modelling work was supported by grants to WHOI from ONR (ONR-URIP. N00014-92-J-1527 and ONR N00014-89-J-1358) and NSF/NOAA GLOBEC (OCE9016893 and NA366P0289).

\section{LITERATURE CITED}

Alldredge AL (1984) The quantitative significance of gelatinous zooplankton as pelagic consumers. In: Fasham MJR (ed) Flows of energy and materials in marine ecosystems. Plenum, New York, p 407-433

Alldredge AL, Madin LP (1982) Pelagic tunicates: unique herbivores in the marine environment. BioSci 32(8):655-663

Andersen $V(1986)$ Effect of temperature on the filtration rate and percentage of assimilation of Salpa fusiformis Cuvier (Tunicata: Thaliacea). Hydrobiologia 137:135-140

Andersen V, Nival P (1988) A pelagic ecosystem model simulating production and sedimentation of biogenic particles: role of salps and copepods. Mar Ecol Prog Ser 44:37-50

Atkinson LP, Paffenhöfer GA, Dunstan W (1978) The chemical and biological effect of a Gulf Stream intrusion off St. Augustine, Florida. Bull mar Sci 28(4):667-679

Banse K (1974) On the interpretation of data from the carbonto-nitrogen ratio of phytoplankton. Limnol Oceanogr 19 : 695-699

Banse K (1982) Cell volumes, maximal growth rates of unicellular algae and ciliates, and the role of ciliates in the marine pelagial. Limnol Oceanogi 27(6):1059-1071

Bathmann UV (1988) Mass occurrence of Salpa fusiformis in the spring of 1984 off Ireland: implications for sedimentation processes. Mar Biol 97:127-135

Berner L. (1967) Distributional atlas of the Thaliacea in the California Current region. CalCOFI Atlas 8

Bishop JKB, Edmond JM, Ketten DR, Bacon MP, Silker WB (1977) The chemistry, biology, and vertical flux of particulate matter from the upper $400 \mathrm{~m}$ of the equatorial Atlantic Ocean. Deep Sea Res 24:511-548

Booth WE, Sondergaard M (1989) Picophytoplankton in the Hauraki Gulf, New Zealand. NZ J mar Freshwat Res 23: $69-78$

Bradford JM, Chapman BE (1988) Epipelagic zooplankton assemblages and a warmcore eddy off East Cape, New Zealand. J Plankton Res 10(4):601-619

Bruland KW, Silver MW (1981) Sinking rates of fecal pellets from gelatinous zooplankton (salps, pteropods, doliolids). Mar Biol 63:295-300

Caron DA, Goldman JC (1990) Protozoan nutrient regeneration. In: Capriulo GM (ed) Ecology of marine protozoa. Oxford University Press, New York, p 283-306

Chan AT (1980) Comparative physiological study of marine diatoms and dionoflagellates in relation to irradiance and cell size. II. Relationships between photosynthesis, growth, and carbon/chlorophyll a ratio. J Phycol 16: $428-432$

Chang FH (1988) Distribution, abundance and size composition of phytoplankton off Westland, New Zealand, February 1982. NZ J mar Freshwat Res 22:345-367

Chisolm SW, Brand LE (1981) Persistence of cell division phasing in marine phytoplankton in continuous light after entrainment to light:dark cycles. J exp mar Biol Ecol 51: $107-118$

Cullen JJ (1982) The deep chlorophyll maximum: comparing vertical profiles of chlorophyll a. Can J Fish Aquat Sci 39: 791-803

Cullen JJ, Eppley RW (1981) Chlorophyll maximum layers of the Southern California Bight and possible mechanisms of their formation and maintenance. Oceanol Acta 4(1): $23-32$

Curl H (1961) Standing crops of carbon, nitrogen, and phosphorous, and transfer between trophic levels, in continental shelf waters south of New York. Rapp P-v Cons Réun int Explor Mer 153:183-189 
Dakin WJ, Colefax AN (1940) The plankton of the Australian coastal waters of New South Wales, Part 1. Publications of the University of Sydney Department of Zoology 1, Sydney

Davis CS (1983) Laboratory rearing of marine calanoid copepods. J exp mar Biol Ecol 71:119-133

Davis CS, Flierl GR, Franks PJ, Wiebe PH (1991) Micropatchiness, turbulence, and recruitment in plankton. $J$ mar Res 49:109-151

Davis CS, Wiebe PH (1985) Macrozooplankton biomass in a warm-core Gulf Stream ring: time series changes in size structure, taxonomic composition, and vertical distribution. J geophys Res 90(C5):8871-8884

Deibel D (1982) Laboratory-measured grazing and ingestion rates of the salp. Thalia democratica Forskal, and the doliolid Dolioletta gegenbauri Uljanin (Tunicata, Thaliacea). J Plankton Res 4(2):99-111

Deibel D (1985a) Blooms of the pelagic tunicate, Dolioletta gegenbauri: are they associated with Gulf Stream frontal eddies? J mar Res 43:211-236

Deibel D (1985b) Clearance rates of the salp Thalia democratica fed naturally occurring particles. Mar Biol 86:47-54

Deibel D (1990) Still-water sinking velocity of fecal material from the pelagic tunicate Dolioletta gegenbauri. Mar Ecol Prog Ser 62:55-60

Dunbar RB, Berger WH (1981) Fecal pellet flux to modern bottom sediment of Santa Barbara Basin (California) based on sediment trapping. Geol Soc Am Bull, Part 1 92:212-218

Eppley RW, Harrison WG, Chisholm SW, Stewart E (1977) Particulate organic matter in surface waters off southern California and its relationship to phytoplankton. I mar Res 35(4):671-696

Eppley RW, Renger EH, Harrison WG (1979) Nitrate and phytoplankton production in southern California coastal waters. Limnol Oceanogr 24:483-494

Field JG, McFarlane G (1968) Numerical methods in marine ecology. 1. A quantitative similarity analysis of rocky shore samples in False Bay, South Africa. Zool afr 3: 119-138

Fortier L, Le Fevre J, Legendre L (1994) Export of biogenic carbon to fish and to the deep ocean: the role of large planktonic microphages. J Plankton Res 16(7):809-839

Fowler SW, Buat-Menard P, Yokoyama Y, Ballestra S, Holm E, Nguyen HV (1987) Rapid removal of Chernobyl fallout from Mediterranean surface waters by biological activity. Nature 329:56-58

Fraser JH (1962) The role of ctenophores and salps in zooplanktor production and standing crop. Rapp P-v Réun Cons int Explor Mer 153:121-123

Fuller AS (1953) Seasonal variation in the plankton and salinity of the Hauraki Gulf, New Zealand. Nature 171 $525-526$

Gifford DJ, Dagg MJ (1991) The microzooplankton-mesozooplankton link: consumption of planktonic protozoa by the calanoid copepods Acartia tonsa Dana and Neocalanus plumchrus Murukawa. Mar microb Food Webs 5:161-177

Hallegraeff GM (1981) Seasonal study of phytoplankton pigments and species at a coastal station off Sydney: importance of diatoms and the nanoplankton. Mar Biol 61: $107-118$

Harbison GR, McAlister VL, Gilmer RW (1986) The response of the salp, Pegea confoederata, to high levels of particulate material: starvation in the midst of plenty. Limnol Oceanogr 31:371-382

Harris TFW (1985) North Cape to East Cape: aspects of the physical oceanography. University of Auckiand Department of Physics and Marine Laboratory, Leigh
Harrison WG (1978) Experimental measurements of nitrogen remineralization in coastal waters. Limnol Oceanogr 23(4): $684-694$

Harrison WG, Platt T, Lewis MR (1985) The utility of light-saturation models for estimating marine primary productivity in the field: a comparison with conventional 'simulated' in situ methods. Can J Fish Aquat Sci 42:864-872

Heron AC (1972a) Population ecology of a colonizing species: the pelagic tunicate Thalia democratica. Individual growth rate and generation time. Oecologia 10:269-293

Heron AC (1972b) Population ecology of a colonizing species: the pelagic tunicate Thalia democratica. II. Population growth rate. Oecologia 10:294-312

Heron AC, Benham EE (1984) Individual growth rates of salps in three populations. J Plankton Res 6:811-828

Heron AC, Benham EE (1985) Life history parameters as indicators of growth rate in three salp populations. J Plankton Res 7(3):365-379

Hildebrand FB (1976) Advanced calculus for applications. Prentice-Hall, Englewood Cliffs, NJ

Iseki K (1981) Particulate organic matter transport to the deep sea by salp fecal pellets. Mar Ecol Prog Ser 5:55-60

Jamart BM, Winter DF, Banse $\mathrm{K}$, Anderson GC, Lam RK (1977) A theoretical study of phytoplankton growth and nutrient distribution in the Pacific Ocean off the northwestern US coast. Deep Sea Res 24:753-773

Jillett JB (1971) Zooplankton and hydrology of Hauraki Gulf, New Zealand. NZ Dept sci ind Res Bull 204

Jonsson PR (1986) Particle size selection, feeding rates and growth dynamics of marine planktonic oligotrichous ciliates (Ciliophora: Oligotrichina). Mar Ecol Prog Ser 33: 265-277

King FD, Devol AH (1979) Estımates of vertical eddy diffusivity through the thermocline from phytoplankton nitrate uptake rates in the mixed layer of the eastern tropical Pacific. Limnol Oceanogr 24(4):645-651

Knauer GA, Martin JH, Bruland KW (1979) Fluxes of particulate carbon, nitrogen and phosphorus in the upper water column of the northeast Pacific. Deep Sea Res 26:97-108

Krause M (1981) Vertical distribution of faecal pellets during FLEX 176. Helgoländer Meeresunters 34:313-327

Kremer P, Madin LP (1992) Particle retention efficiency of salps. J Plankton Res 14(7):1009-1015

Landry MR, Hassett RP, Fagerness V, Downs J, Lorenzen CJ (1984) Effect of food acclimation on assimilation efficiency of Calanus pacificus. Limnol Oceanogr 29:361-364

Le Borgne R, Moll P (1986) Growth rates of the salp Thalia democratica in Tikehau Atoll (Tuamotu Is.). Oceanogr tropicale 21(1):23-29

Lorenzen CJ (1966) A method for the continuous measurement of in vivo chlorophyll concentration. Deep Sea Res 13:223-227

Madin LP (1982) Production, composition and sedimentation of salp fecal pellets in oceanic waters. Mar Biol 67:39-45

Madin LP, Cetta CM, McAlister VL (1981) Elemental and biochemical composition of salps (Tunicata: Thaliacea). Mar Biol 63:217-226

Manly BFJ (1994) Notes for a three day workshop on computer intensive statistics in biology. University of Otago Dunedin

Margalef DR (1958) Temporal succession and spatial heterogeneity in phytoplankton. In: Buzzati-Traverso AA (ed) Perceptions in marine biology. University of California Press, Berkeley, p 323-349

Michaels AF, Silver MW (1988) Primary production, sinking fluxes and the microbial food web. Deep Sea Res 35(4): $473-490$ 
Morris RJ, Bone Q, Head R, Braconnot JC, Nival P (1988) Role of salps in the flux of organic matter to the bottom of the Ligurian Sea. Mar Biol 97:237-241

Mountford MD (1962) An index of similarity and its application to classification problems. In: Murphy PW (ed) Progress in soil zoology. Papers from a colloquium on research methods organized by the Soil Zoology Committee of the International Society of Soil Science held at Rothamstead Experimental Station, Hertfordshire, 10-14 July 1958. Butterworths, London, p 43-50

Mullin MM (1983) In situ measurement of filtering rates of the salp. Thalia democratica, on phytoplankton and bacteria. J Plankton Res 5(2):279-288

Omori M (1969) Weight and chemical composition of some important oceanic zooplankton in the North Pacific Ocean. Mar Biol 3:4-10

Paffenhöfer GA, Knowles SC (1979) Ecological implications of fecal pellet size, production and consumption by copepods. J mar Res 37(1):35-49

Paffenhöfer GA, Lee TN (1987) Development and persistence of patches of Thaliacea. In: Payne AIL, Gulland JA, Brink $\mathrm{KH}$ (eds) The Benguela and comparable ecosystems. S Afr J mar Sci 5:305-318

Parker K (1991) Eddy diffusion of phytoplankton and nutrients: estimating coefficients from simulated and observed vertical distributions. J Plankton Res 13:815-830

Parsons TR, Takahashi $M$, Hargrave B (1988) Biological oceanographic processes. Pergamon Press, Oxford

Paul LJ (1968) Some seasonal water temperature patterns in the Hauraki Gulf, New Zealand. NZ J mar Freshwat Res 2(3):535-558

Pomeroy LR, Deibel D (1980) Aggregation of organic matter by pelagic tunicates. Limnol Oceanogr 25(4):643-652

Pomeroy LR, Hanson RB, McGillivary PA, Sherr BF, Kirchman D, Deibel D (1984) Microbiology and chemistry of fecal products of pelagic tunicates: rates and fates. Bull mar Sci 35(3): 426-439

Proctor R, Greig MJN (1989) A numerical model investigation of the residual circulation in Hauraki Gulf, New Zealand. NZ J mar Freshwat Res 23:421-442

Roache PJ (1982) Computational fluid dynamics. Hermosa Publishers, Albuquerque

Sharples J, Greig M (1993) Review of 1: Hauraki Gulf winddriven residual circulation 2: Sea surface temperature and

This article was submitted to the editor salinity during the 1992-93 toxic algal bloom. Unpublished report prepared for the Ministry of Agriculture and Fisheries, held in NIWA - Oceanographic library, Wellington

Sheard K (1953) Taxonomy, distribution and developoment of the Euphausiacea (Crustacea). Rep BANZ Antarctic Res Exped 8:1-72

Small LF, Fowler SW, Ünlü MY (1979) Sinking rates of natural copepod fecal pellets. Mar Biol 51:233-241

Smetacek VS (1985) Role of sinking in diatom life-history cycles: ecological, evolutionary, and geological significance. Mar Biol 84:239-251

Stainton MP (1974) Simple, efficient reduction column for use in automated determination of nitrate in water. Analyt Chem 46:1616

Steele JH, Yentsch CS (1960) The vertical distribution of chlorophyll. J mar biol Ass UK 39:217-226

Strickland JDH, Parsons TR (1972) A practical handbook of seawater analysis. Bull Fish Res Bd Can 167

Strom SL (1991) Growth and grazing rates of the herbivorous dinoflagellate Gymnodinium sp. from the open subarctic Pacific Ocean. Mar Ecol Prog Ser 78:103-113

Turpin DH, Harrison PJ (1979) Limiting nutrient patchiness and its role in phytoplankton ecology. J exp mar Biol Ecol 39:151-166

Underwood AJ (1981) Techniques of analysis of variance in experimental marine biology and ecology. Oceanogr mar Biol A Rev 19:513-605

Urrere MA, Knauer GA (1981) Zooplankton fecal pellet fluxes and vertical transport of particulate organic material in the pelagic environment. J Plankton Res 3:369-387

Waite A, Thompson PA, Harrison PJ (1992) Does energy control the sinking rate of marine diatoms? Limnol Oceanogr $37(3): 468-477$

Wilkinson L (1988) Systat: the system for statistics. Systat, Inc, Evanston, IL

Zeldis JR (1991) Ichthyoplankton studies for fisheries research. Larval Fish Workshop, Australian Society for Fish Biology Workshop, Hobart, 20 August 1991. Bureau Rural Resources Proc 15:19-26

Zeldis JR (1993) Hydrography of the northeastern North Island associated with the 1992-93 algal blooms. Unpublished report prepared for the Ministry of Agriculture and Fisheries. Held in NIWA Greta Point library, Wellington

Manuscript first received: February 24, 1994 Revised version accepted: February 16, 1995 